Euskal ikerketen aldizkaria | Revue d'études basques |

Revista de estudios vascos | Basque studies review

Numéro spécial 3 | 2015

Euskal hizkera eta dialektoak gaur egun

\title{
Dialektologia dinamikoa
}

José Ignacio Hualde

\section{OpenEdition}

Journals

Édition électronique

URL : http://journals.openedition.org/lapurdum/2656

DOI : 10.4000/lapurdum.2656

ISSN : 1965-0655

Éditeur

IKER

Édition imprimée

Date de publication : 1 novembre 2015

Pagination : 125-153

ISBN : 9782955341322

ISSN : $1273-3830$

\section{Référence électronique}

José Ignacio Hualde, « Dialektologia dinamikoa », Lapurdum [Linean], Numéro spécial 3 | 2015, Sarean emana---an 12 juillet 2017, kontsultatu 20 avril 2019. URL : http://journals.openedition.org/ lapurdum/2656 ; DOI : 10.4000/lapurdum.2656 


\section{Dialektologia dinamikoa}

José Ignacio HUALDE

University of Illinois at Urbana-Champaign

\section{Laburpena}

Gaur egun, arlo honetan lan egiten dugun ikertzaileok ados gaude Euskara Batu Zaharra (EBZ) — hau da, euskalki guztien azken ahaide komuna—Akitanieraren aztarnak eta Mitxelenaren berreraikuntza fonologikoa baino askoz berriagoa dela. Ikerkuntzaren egoera honetan, garrantzitsua da bilakaera fonologiko eta morfologiko desberdinak EBZaren kronologian txertatzea eta beren hedadura geografikoa eta dialektala zehaztea momentu historiko desberdinetan. Artikulu honetan gertakari batzuk kontsideratzen ditut ikuspegi honetatik. Besteak beste, afrikatuen banaketa, bokalen arteko sudurkarien ahultzea eta silabahasierako irristari sabaikarien garapena aztertzen ditut. Honetaz gain, ikerketa honek dituen zailtasun batzuk ere aipatzen ditut.

\section{Sarrera ${ }^{1}$}

Artikulu honekin egin nahiko nukeen ekarpena xumea da. Funtsean aldarrikatu nahi dut denboraren eta espazioaren ardatzak batera kontuan hartzea argigarria izan daitekeela hizkuntza baten historiaz ikasteko. Era berean, dialektologian ere aurrerago joan gaitezke ikuspegi diakronikoa eransten diogunean diatopikoari.

Ideia ez da batere berria edo originala. Egia esan, artikuluaren izenburua bera 1990eko liburu bati mailegatu diot: Mieko Ogura, Dynamic dialectology: A study of language in time and space. Dena den, kontzeptua berri-berria ez bada ere, euskalaritzari dagokionez, uste dut merezi duela denboraren eta geografiaren arteko erlazioaz hausnarketa gehiago egitea, azken

1. Nire esker ona bihoakie Iñaki Caminori, Joseba Lakarrari eta Julen Manterolari artikuluaren lehen bertsioa irakurtzeagatik eta egin dizkidaten ohar eta zuzenketengatik. Omnia peccata mea sunt. 
urte hauetan beste ikerlari batzuk egiten hasi diren bezala (cf Urgell 2006², Camino 200833, 2011, 2013, Zuazo 2010, 2014, Lakarra 2011, Aldai 2012, Reguero 2013). Beste zenbait euskalarik irekitako ildotik noa, beraz, hemen. Bereziki, lantxo xume honek Lakarraren (2011) artikulu mardularekin duen zorra hasieratik aitortzen dut. Honek ez du esan nahi, hala are, horko eta hemengo iritziak bat datozenik beti. Batzuetan, bai; beste batzuetan, ez.

Dialektologia dinamikoaren lan nagusia zera izango litzateke: isoglosak nola sortu eta aldatu diren ikertzea.

Diakronikoki, euskal dialektologia Mitxelenak (1981) definitzen duen euskara batu zaharrarekin (EBZ) hasten da. Hasiko gara, beraz, kontzeptu honekin. 2. eta 3. ataletan gogoeta batzuk egiten ditut EBZaren eta proto-hizkuntzaren kontzeptuen inguruan. 4. atalean kontsideratzen dut zein neurritan jakin dezakegun ziurtasunez aldakuntza bat EBZa baino zaharragoa den ala ez. 5. Atalean saiatzen naiz fenomeno fonologiko batzuk (herskarien eta txistukarien banaketa, sudurkarien galera eta hitz-hasierako iodaren garapena) EBZaren kronologian kokatzen. Euskarak baliabide batzuk garatu ditu maileguak egokitzeko. 6. atalean aztertzen ditut egokitzapen arauek sortzen dituzten arazoak gertakari fonologikoen kronologia zehazterakoan. Azkenik, 7. atalean dialektologia dinamikoaren zeregin eta betebeharraz arituko naiz.

Hurrengo atalaren izenburua Mitxelenari mailegatzen diot.

\section{Hizkuntzak eta proto-hizkuntzak}

Hizkuntzak izate errealak dira. Ziur gaude mintzatzen edo mintzatu egin direla. Beste garai batekoak badira — hala nola iberiera, latina edo ingeles zaharra — izkribuzko aztarnak utzi dizkigutelako ezagutzen ditugu. Proto-hizkuntzak, aldiz, hipotesiak dira, asmakuntzak.

Ikerlari batzuek proto- eta pre- aurrizkien artean bereizten dituzte hizkuntzalaritza historikoaren hipotesiak izendatzeko. Tradizio honetan, proto-hizkuntza bat (adib. ProtoWestern Germanic edo proto-mendebaldeko germanikoa) hizkuntza talde edo familia baten azken ahaide komuna da eta metodo konparatiboaren bidez berreraikitzen da. Aldiz, preaurrizkia erabiltzen da barne-berreraiketaren ondorioak izendatzeko (adib. Pre-Old English edo pre-ingeles zaharra; ingeles zaharrezko testuak baino lehenagoko hizkuntza egoera bat).

Adibide bat emateko, galaiko-portugesa, astur-leonesa, gaztelania eta nafar-aragoiera erkatuz proto-hispano-erromanikoa (PHE) berreraiki dezakegu, metodo konparatiboa erabiliz

2. "Para extraer conclusiones históricas válidas [...] habría que trabajar a la vez en el eje espacial y temporal de los datos" (Urgell 2006: 941).

3. "Dialektologiaz dihardugunean kronologiaz jardun behar dugu baitezpada, hizkuntzaren historia eta dialektoen azterketa uztarturik baitaude" (Camino 2008: 209). 
(katalana hizkuntza galo-erromanikoen artean kokatzen da historikoki ${ }^{4}$ eta horregatik alde batera uzten dugu konparazio honetarako). Etsenplu gisa, metodologia honen aplikazioak eramaten gaitu $\mathrm{PHE} * / \mathrm{ou} \mathrm{u}$ 'begi' proposatzera (cf. gal-port. olho, ast-len güeyu, gazt ojo, naf-arag. güello), eta era berean PHE */luna/ 'hilargi'/ (cf. gal-port. lua, ast-leon lluna, gazt. \& naf-arag. luna), PHE */fiKu/ 'seme' (cf. gal-port. filho, ast-leon. fiu, gazt. hijo, naf-arag. fillo), eta PHE */nointe/ 'gau' (cf. gal-port. noite, ast-leon. nochi, gazt. noche, naf-arag. nueite). Erkaketan, hizkuntza hispaniko-erromanikoez gain, galo-erromanikoak eta rhaeto-erromanikoak sartzen baditugu (edo, zehazkiago, proto-hispano-erromanikoa, proto-galo-erromanikoa eta proto-rhaeto-erromanikoa konparatuz), ahaide zaharrago bat berreraiki dezakegu, hots, mendebaldeko proto-erromanikoa. Azkenik, familia honetako hizkuntza guztiak kontuan hartuz, proto-erromanikora (PE) iristen gara, erromatar inperioa apurtu baino lehenagoko garaian datatu dezakeguna. Gure lehen adibidearekin segituz, ital. occhio /okkjo/, errum. ochi /okj/, etab, kontuan hartuz, PE */okKu/ 'begi' edo antzeko zerbait lortzen dugu.

Kontua da, hizkuntza erromaniko guztien $\mathrm{ama}^{5}$ ezaguna dela: latina. Eta, hemen dago koska, latinaren datu errealak eta metodo konparatiboa aplikatuz postula ditzakegun hipotetikoak ez dira beti berdinak. Badakigu, esaterako, latinez 'begi' oculus esaten zela, edo oculum kasu akusatiboan, baina, esan bezala, gure metodologiak PE */okKu/ edo antzeko zerbait ematen digu, bi silabarekin bakarrik (era berean, 'berde' hitzak bi silaba ditu erromantze guztietan eta, ondorioz, bi silabarekin berreraiki behar, nahiz eta latinez viridis izan, etab.). Normalean pentsatzen da desadostasun hauen arrazoiak latinaren barneko bariazio diatopiko, diakroniko eta diastratrikoan bilatu behar direla. Latin klasikoan idatzitako testuek oso irudi homogeneoa eskaintzen badigute ere, pentsatzekoa da latina ez zela garai, leku eta klase sozial guztietan berdin ahoskatzen. Ezagutzen ditugun hizkuntza guztiek bezala, bariazio soziolinguistikoa izan behar zuen. Pozgarria da erromanistentzat, alde honetatik, latin vulgar delakoaren aztarnek metodo konparatiboaren hipotesiak baieztatzen dituztenean, askotan gertatu den bezala (cf. adib. Herman 1967), honek erakusten baitigu metodoak funtzionatzen duela. Hizkuntza idatziak kontserbatzaileak direnez, zenbait gauzatan latin klasikoa protoerromanikoa baino zaharragoa da. Nekez berreraikiko genuke latin klasikoaren deklinabide osoa metodo konparatiboaren bidez.

Metodo konparatiboak, dena den, muga ezagunak ditu eta egia historikora hurbiltzen bagaitu ere, maiz ez digu egia osoa esaten. Hizkuntzen arteko korrespondentziak argi daudenean ere, askotan proto-formen errealitate fonetikoa iluna da: nola ahoskatzen zuten *dhghem- 'lur' indoeuroparrek, adibidez? Kontsidera dezagun adibide askoz modernoago eta (beraz) argiago bat. Gaur egungo Iberiar penintsulako (ipar eta erdialdeko) gaztelania, Latinamerikakoa eta Mediterraneoko ekialdekoa edo judeo-espainola erkatzen baditugu, hurrengo korrespondentzia sistematikoak aurkitzen ditugu txistukariekin:

4. Hitz-bukaerako /-u/ azentugabea galdu baitzuen, geroago hizkuntza hispano-erromanikoei hurbildu bazitzaien ere eta $/ \mathrm{u} />/ \mathrm{y} /$ aldakuntza ez zuen pairatu.

5. Tradizioz, hizkuntzak emakumezkoak dira: mother, daughter, sister language. 
(1) Gaztelaniaren dialektoak: txistukarien arteko korrespondentziak

\begin{tabular}{|c|c|c|c|}
\hline \multirow[b]{2}{*}{ I. } & Espainia & Latinamerika & Turkia \\
\hline & /braقo/ & /braso/ & /braso/ \\
\hline \multirow{3}{*}{ II. } & /kabe日a/ & /kabesa/ & /kavesa/ \\
\hline & /de日ir/ & /desir/ & /dezir/ \\
\hline & /äer/ & laser/ & /azer/ \\
\hline \multirow[t]{2}{*}{ III. } & /paso/ & /paso/ & /paso/ \\
\hline & lese/ & lese/ & lese/ \\
\hline \multirow[t]{2}{*}{ IV. } & /beso/ & /beso/ & /bezo/ \\
\hline & /kasa/ & /kasa/ & /kaza/ \\
\hline
\end{tabular}

Hemen lau korrespondentzia sistematiko ditugunez gero, lau fonema postulatu behar ditugu, hiru dialekto hauek konparatuz berreraiki dezakegun proto-gaztelaniarako: bi hortzarteko frikari, ahoskabea */ $\theta /\left(* / \mathrm{bra} \theta \mathrm{o} /,{ }^{*} / \mathrm{kabe} \theta \mathrm{a} /\right)$, eta ahostuna */ð/ (*/deðir/, */aðer/) eta bi hobikari, ahoskabea */s/ (*/paso/, */ese/) eta ahostuna */z/ (*/bezo/, */kaza/). Kasu honetan, gure proto-hizkuntza oso zehazki datatu dezakegu: 1492 urtea dugu terminus a quo. Urte horretan hasi zen hiru hizkeren banaketa geografikoa. Ertaroko gaztelania, noski, oso ongi dokumentatuta dago. Dakigunaren arabera, hizkuntza honek lau kontsonante desberdin zituen emandako adibideetan, gure berreraikuntza puntu honetan baieztatuz. Hala ere, izate fonetikoari dagokionez, lau kontsonante horietako batzuk ez ziren berreraiki bezala:

(2) Txistukariak proto-gaztelaniaz eta ertaroko gaztelaniaz

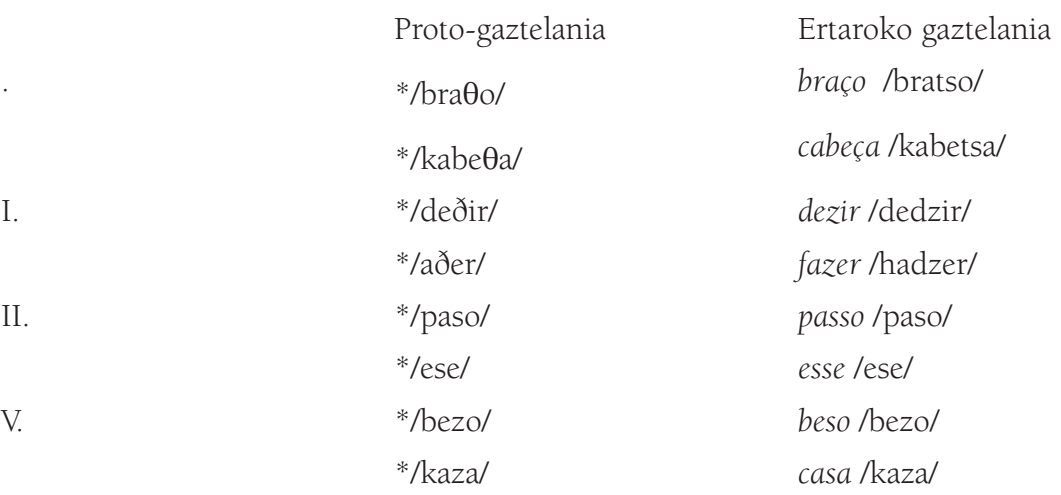

Ziur asko 1492 urterako afrikatu zaharrak frikariak ziren leku gehienetan, baina ez dirudi hortzartekoak zirenik; /s/ > / $\theta$ / aldakuntza beranduago gertatu zen Gaztelan; eta */d/ fonema hipotetikoa ez dator bat errealitatearekin. 
Adibide honekin metodo konparatiboaren mugak erakutsi nahi izan ditut, korrespondentzia sistematikoak erabiliz berreraiki ditzakegun proto-hitzen ahoskera den bezainbatean.

Eman ditudan adibideetan reality check bat egin dezakegu, konparatu ditugun hizkuntzen ama dokumentatuta baitago: proto-erromaniko hipotetikoa testuetako latinarekin erka dezakegu eta proto-gaztelania ertaroko gaztelaniarekin. Baina, kasu hauek salbuespenezkoak dira. Gehienetan ez dago testurik gure hipotesiak baieztatzeko ala ezeztatzeko. Proto-indo-europeraren kasuan, ezagunak dira berreraikitako fonema batzuen errealitate fonetikoari buruz dauden eztabaidak, nahiz eta korrespondentziak neurri handi batean argi egon. Euskararen fonologia historikoaren eremuan, Mitxelenaren fortis/lenis edo bortitz/ahul oposaketa fonologikoaren interpretazio fonetikoan dugu auzia.

Metodo konparatiboaz gain, hizkuntza baten historia ezagutzeko dugun beste tresna garrantzitsua barne-berreraiketa da. Esan bezala, goian aipatu dudan terminologian, preaurrizkia erabiltzen da barne-berreraiketaren bidez lortutako hipotesiak izendatzeko. Adibide bat emateko, ingeles zaharraren /mu:s/ 'sagu' eta bere plurala /my:s/ eta antzeko beste adibide batzuk konparatuz, pre-ingeles zaharrerako - hau da, ingeles zaharra baino lehenagoko hizkuntza egoera baterako— */mu:si/ 'saguak' lortzen dugu. ${ }^{6}$

\section{Antzinako euskara(k), euskara batu zaharra, akitaniera}

Euskalaritzaren arlora etorriz, badirudi denok onartzen dugula orain gaurko euskalki eta euskal hizkeren desberdintze prozesua ertaroan hasi zela, Mitxelenak (1981) proposatu bezala, eta ez erromatarren garaian edo lehenago (ikus Zuazo 2010, Lakarra 2011). Ertaroko hizkuntza hori — gaurko euskal hizkera guztien ama dena—izendatzeko euskara batu zaharra (EBZ) terminoa erabili ohi da. EBZa beharbada IV. eta VI. mendeen artean datatu daiteke, agian Iruñaldean kokatua (ikus Zuazo 2010) edo "Iruñearen iparraldera" (Lakarra 2011: 215). Litekeena da handik zabaldu izana Nafarroako erresumaren hedapenarekin batean, familia bereko beste dialektoen eta beharbada beste hizkuntza batzuen kaltetan. Bestaldetik, hizkuntza erromanikoen artean, gaskoiera denez euskararekin antza handiena duena bere fonologia diakronikoan (Allières 1992), hau ere kontuan hartu beharko litzateke EBZa geografikoki kokatzerakoan.

Euskararen aztarnak IV. mendea baino zaharragoak direnez, eta eskualde askoz zabalago batean aurkitzen direnez, badirudi onartu behar dugula EBZak ahaideak izan zituela, baina hauek ez dutela iraun. Erromatarren garaian hitz egiten zen euskararen arbasoa akitaniera deitzen da lan askotan (Gorrotxategi 1984), hizkuntza edo hizkuntza talde honek batez ere Akitanian utzi baitizkigu aztarnak (baina ez eskualde horretan bakarrik). Zentzuzkoa dirudi

6. Euskarazko terminologia dela-ta, beharbada pre- $=$ aurre- , proto- $=$ aitzin- (Joseba Lakarraren iruzkina). 
pentsatzeak akitanierak zatikatze dialektala ezagutu zuela. Hau da, erromatarren garaiko akitanieraren alaben artean, batek bakarrik iraun zuen bizirik, EBZ izenarekin ezagutzen dugunak, eta hori da geroko testuetan agertzen zaizkigun eta gaur egun hitz egiten diren euskara mota guztien ama edo jatorria (ikus Campbell 2011, Lakarra 2011, Reguero 2013).

Beharbada EBZa lehenagoko bateratze prozesu baten ondorioa zen, edo beharbada leku edo gizatalde jakin bateko hizkera nagusitu zen, besterik gabe. Hau ezin jakin. Ez dut pisuzko arrazoirik ondorioztatzeko EBZa lehenagoko bateratze prozesu baten ondorioa zenik, halabeharrez. Esan bezala, beste aukera da hizkera jakin bat gailendu zela familia bereko beste hizkeren artean. Konparaziorako, latinak ahizpa bizkiak (faliskoa), lehengusinak (oskoa, unbroa) eta ahaidetasunik gabeko beste hizkuntza batzuk (etruskera) ordezkatu zituen Italian zehar hedatu zenean. Denboraz hurbilago dugun judeo-espainolaren kasuan, nolabaiteko bateratze prozesu bat aurkitzen dugu hizkuntza hispano-erromaniko desberdinen hiztunak batu baitziren Otomandar inperioko komunitate berrietan, baina hizkuntzaren oinarria gaztelania da, eta ez da hizkuntza hispano-erromaniko hibrido bat, aragoieraren, portugesaren eta beste zenbait hizkuntzaren zenbait elementu bere baitan hartu baditu ere (Quintana 2006).

Bai Lakarrak (1995, 2011, etab) berreraikitzen duen hizkuntza eta baita Mitxelenaren antzinako euskara (AE) ere EBZa baino zaharragoak dira. Argi dago Lakarraren berreraiketa akitanierazko inskripzioak baino aurreko garai bati dagokiola, inskripzioetan aurkitzen ditugun hitz gehienak edo guztiak — hala nola CISON, ANDERE, Lergako VMME, SAHAR, Soriako SESENCO (Gorrotxategi 2009), etab- polisilabikoak baitira eta, ondorioz, polimorfemikoak, hipotesi honen arabera. Hau honela izanik, Lakarraren berreraiketa pre-akitaniera bezala identifika dezakegu. Mitxelenaren AE, aldiz, ez dago hain garbi akitaniera baino aurrekoagoa, akitanieraren garaikidea edo modernoagoa den. Posible da, noski, Mitxelenaren etimologia guztiak garai berekoak ez izatea. Itzuliko gara gai honetara. Hona hemen garapen batzuk:

(3) Adibide batzuk

andere, andre $<$ EBZ andere $<$ akit ANDERE $<$ AE andere $<$ pre-akit *and- ${ }^{7}$

gizon, gizun < EBZ gizon < akit cIs(s)on < pre-ak * gi- +zon (Lakarra 1995)

(h) ume $<$ EBZ hume $<$ akit VMME, OMBE $<\mathrm{AE}$ *hun+ -be?

inude, unide $<$ EBZ unide $<$ akit vMME- $<$ AE *hun+ide

sein, sehi $<$ EBZ seni $<$ akit sENI- $<$ pre-ak *sen-

ardo, ardao, ardũ $<$ EBZ $\operatorname{ardãõ~}<\mathrm{AE} *$ ardano $<$ pre-akit *e-da-ra-dan

(Lakarra 2008)

Dauzkagun datuen eta hipotesien arabera, honelako zerbait izango genuke, beraz:

7. Cf. Gorrotxategi (1995:42). Ez Lakarrarentzat, berreraikitzen duen erro kanonikotik aldenduko bailitzakete. 
Noiz?

*Pre-akitaniera (Lakarra)

I. mendea:

IV-VI. mendea:

Akitaniera

$=$

*AE (Mitxelena)?

XVI-XVII. mendea:

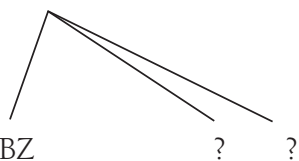

1. irudia: Akitanieraren bilakaera diakronikoa.

EBZa eta bere dialektoak direla eta, Lakarrak (2011) arrazoia du, noski, esaten digunean marraztu dugun zuhaitz lauak ez duela historia osoa kontatzen. Euskalki modernoak ez ziren denak aldi berean desberdindu bata bestetik. Guztiz alderantziz, aldaketa garrantzitsu bakoitzak adarkatze dialektal bitar bat eragin zuen, halabeharrez: alde batetik, A > B aldakuntza pairatu zuen hizkera multzoa dugu, eta bestetik, pairatu ez zuena. Hau hola bada ere, interesatzen zaiguna bi garai desberdin erakustea baldin bada, besterik gabe, uste dut sinplifikazio hau justifika daitekeela, are gehiago dialektalizazioaren diakronia oraindik oso argi ez dagoenez. Adarkatze bitar egokiena determinatzeko, hizkerak bereizteko erabiltzen ditugun aldaketen datazio erlatiboa funtsezko lana da (ikus Camino 2008: 221, Camino 2013: 98).

Beste aldetik, aspaldidanik da gauza ezaguna zuhaitz eredua ez dela nahikoa, beste eredu teoriko batzuekin osatu behar dela, ama hizkuntza baten alaben arteko kontaktuak iraun duenean, gure kasuan bezala (ikus Camino 2013: 88-89). Pentsatzen dut Labov-ek (2007) plazaratu duen ezaugarri linguistikoen transmisioaren eta difusioaren arteko bereizkuntza oso erabilgarria izanen litzatekeela euskararen historia ulertzeko.

EBZezko testurik ezagutzen ez dugunez gero, EBZak proto-hizkuntza baten estatusa izan behar du. Hau da, EBZera hurbildu gaitezke metodo konparatiboa aplikatuz. Hurrengo adizkiak, adibidez, izango lirateke EBZarenak: *daud, *dauk, *daun, *dau, *daugu, *dauzu, eta, beharbada, *daude.

(4) $\quad$ EBZ *edun

dau, du $<$ EBZ *dau $<$ pre-EBZ *dadu

dut, det, dot, erronk dud $\sim$ dur $<$ EBZ *daud $<$ pre-EBZ *daduda

daude, dabe, due, dute < EBZ *daude $<$ pre-EBZ *dadude 
Berreraiketa honetan, arazo fonetikoak sortzen dituen forma bakarra dute da. Beharbada atzizkiaren /-t-/-aren azalpena da kontsonante baten ondoren atzizkietan aurkitzen dugun herskarien gorketa, irristari baten ondoren ere eman zitekeela, cf. zauku 'zaigu' eta, eratorpenean, -dar atzizkiarekin adibidez, *arabadar $>$ arabaar $>$ arabar, *izabadar $>$ izabar vs *uztarrozdar > uztarroztar, eta baita ere bizkaitar, diptongoarekin. (Konparaketarako, mendebaldeko erromantzeetan ahoskabeak ez dira ahostuntzen irristari baten ondoren: LACU $>$ gazt. lago vS PAUCU > poco; SAPET > sabe vs SAPIAT > *saipat > sepa).

Barne-berreraiketaren bidez, urrunago joan gaitezke. Abibidez, dut/dudala, dudana eta duk/duala/duan txandaketek, eta dadukat, etabarreko adizkiekiko konparaketak eramaten gaituzte *daduda, *daduga postulatzera EBZa baino lehenagoko garai baterako (ikus Gómez \& Sainz 1995, Trask 1997: 233).

Aditz morfologian badira oraindik ere askatu gabeko korapilo asko; adibidez, zaio eta jako ez dira hain erraz bateratzen. Beharbada EBZ *diaigio? (zaio < *diai (g)io; zaizkio < *diaizgio; jako <*diako $<$ *diaikio (-k- pluralarekiko analogiaz) $<*$ diaigio).

Bestalde, metodo konparatiboa erabiliz, EBZaren azentuera ere berreraiki dezakegu. Honi buruzko nire azken saiaketarako, ikus Hualde (2012). Elordieta \& Egurtzegiren (2014) proposamena lehenagoko garai bati dagokio.

Fonologiazko alderdi gehienetan, hizkera historikoen arteko diferentziak oso ttikiak dira eta, beraz, metodo konparatiboak ez gaitu oso urrun eramaten. Urrunago joan gaitezke barne-berreraiketaren bidez, Mitxelenak erakutsi zigun bezala. Barne-berreraiketaz gain, euskararen kasuan, maileguek jasotzen dituzten aldaketak erabili ditzakegu fonologia historikoa egiteko. Hizkuntzalaritza historikoaren arloan, Mitxelenak (1985[1961], 1974), beste gutik bezala, jakin zuen maileguek eman diezaiguketeen ebidentziaz baliatzen hizkuntz berreraiketarako. 5. atalean zenbait gertakari fonologiko kontsideratuko ditugu. Hori egin baino lehen, hurrengo atalean esplikatu nahi dut zergatik ez den zilegi euskaraz orokorra den guztia EBZari esleitzea eta zergatik ez den beti hain begi-bistakoa zer dagokion EBZari eta zer den berriagoa (cf Mitxelena 1981).

\section{EBZa eta arau diakronikoen kronologia: EBZa baino lehen?}

Arau diakronikoen dataketan, printzipioz, erraza izan beharko luke jakiteak aldakuntza jakin bat EBZa baino lehen ala ondoren gauzatu zen. Aldakuntza euskalki batzuetan bakarrik aurkitzen bada, EBZa baino berriagoa izan behar du, definizioz. Talde honetako aldakuntza garrantzitsuenen artean ditugu adibidez mendebaldeko / $-\mathrm{a}+\mathrm{a} / \mathrm{>} / \mathrm{-e}+\mathrm{a} /$ disimilazioa singularrean (alabaa > alabea) eta herskarien ahostuntzea albokari edo sudurkari baten ondoren (alte > alde), euskalki guztietan ez baitira gertatzen. Lakarraren (2011) ustez, azken bilakaera hau izango litzateke dialekto-muga garbi bat markatzen duen lehenetarikoa: 
zuberera eta erronkariera vs besteak. ${ }^{8}$

Beste aldetik, euskalki guztiek forma berbera erakusten badute, barne-berreraiketaren bidez aurki ditzakegun aldakuntza diakronikoak EBZa baino zaharragoak izan beharko lukete, printzipioz.

Hala ere, esan duguna ez da beti horrela. EBZa apurtu eta gero ere, euskal hizkerak kontaktuan egon dira elkarrekin, eta oso posible da euskalki batean hasi zen berrikuntza bat bere eremutik kanpo eta baita Euskal Herri osora ere zabaldu izana.

Morfologiazko adibide argi bat emateko, adizkien analisi morfologikoak argi eta garbi erakusten digu garai batean zu izenordaina plurala zela. Garai eta leku guztietako euskara historikoan, aldiz, izenordain hau singularreko bigarren pertsona bezala erabili eta erabiltzen da. Arrazoizkoa dirudi pentsatzea lehen pausua izan zela pluralaren esanahiari errespetuzko singularraren balioa eranstea, inguruko erromantzeetan gertatu den bezala. Hau da gaztelania zaharrean aurkitzen duguna eta orain arte frantsesez mantendu den egoera, non vous izenordainak bi erabilera horiek baititu. Metodo konparatiboa aplikatuz, ondorioztatu behar dugu $2 p l>2 p l \&$ errespetuzko 2sg aldakuntza EBZa baino lehen gertatu zela, orokorra baita euskaraz. Hala ere, ezin dugu baztertu aldakuntza modernoagoa izatea, eta Euskal Herri osoan zehar zabaldu izana zatiketa dialektala hasi eta gero.

Euskalki guztietan bilakaera honetan urrats bat aurrerago eman da. Noizpait $z u$ izenordainak jatorrizko balio plurala galdu zuen eta forma berri bat, zuek, sortu zen balio honekin. Antzeko garapenak ikusten ditugu inguruko erromantzeetan (gaztelaniaz eta okzitaniera/katalaneraz), baina ez urrutiagokoetan (frantsesez ${ }^{9}$ edo portugesez). Iruditzen zait ondorioztatu behar dugula bigarren aldaketa hau nahikoa berria dela, alboko erdaretan bezala, nahiz eta Euskal Herri osora zabaldu den. Are gehiago, testuek erakusten digute zarete, duzue bezalako formak are berriagoak direla; zuek izenordaina baino berriagoak. Hasiera batean, zu eta zuek izendordainek komunztadura bera eragiten zuten: zu zara eta zuek zara. Komunztadura mota hau nahikoa berandu arte mantendu bazen ere leku batzuetan, gaurregun zaralzare $(t) e$ bereizkuntza morfologikoa orokorra da. Adizkietako berrikuntza hau berezia da euskaraz eta ez du paralelorik hizkuntza erromanikoetan; zabaldu bada, ez da erdararen eragin zuzenagatik izan. Nonbait hasi zen eta handik hedatu zen Euskal Herri osora azken mende hauetan. Argi

8. Ez dakit nola interpretatu behar diren Lakarrak (2011: 209) aipatzen dituen datu batzuk, Miguel Ros erronkariarrak 1616-1617 urteetan idatzi zituen gutunetatik hartuta. Lakarrak erakusten duenez, erronkarieran ezaugarri ezagun batzuk, hala nola erakusleen hasierako k-, (ia) ez dira agertzen gutun horietan. Horretaz gain, geroagoko Erronkariko datuetan ez bezala, ahostunak aurkitzen ditugu deklinabideko -ti(k) eta -ko atzizkiekin: nongo, emendi, emengoez (ikus erronk. nonko, kebenti kementi, kebenko geroagoko testuetan, Estornés Lasa 1997 s.v. aquí).

9. Frantsesez vous autres eta italieraz voi altri aurkitzen baditugu ere, forma hauek ez dira gramatikalizatu. 
dago, beraz, dialekto guztietan aurkitzen diren berrikuntza guztiak ez direla nahitaez EBZa baino zaharragoak. Inplikazioak bakarrik norabide batean funtzionatzen du.

Beste mota bateko adibide bat emateko —zentzu batean kontrako adibide batmendebaldeko alabea vs alabaak (> alábak) ikusita, Mitxelenak (1981) hauxe idatzi zuen: "el plural como el locativo sing. se formó en vasco en época ya tardía, cuando la ley que convertía $a-a+-a$ en -ea, etc., ya no era operante" (306 or.). Disimilazio araua mendebaldeko hizkeretan bakarrik gertatzen denez, honen interpretazioa izan liteke plural morfologikoa sortu zela EBZa baino beranduago eta hedatu zela euskalkietan zehar. Dena den, ez da pentsatu behar plurala bat-batean sortu zenik. Guztiz alderantziz, ziur asko, pluralezko atzizkien garapena prozesu luzea izan zen, pausu desberdinak izan zituena (ikus Manterolaren 2015a ikerketa sakon eta argigarria erakusleen gramatikalizazioaz). Mitxelenak esaten duena azken urratsari bakarrik aplikatzen zaio zuzenean: forma (erlatiboki) askeak zirenak atzizki bihurtu ziren mendebaldean singularrean gertatu zen disimilazioak emankortasuna galdu eta gero. Egitura sintaktikoa, (adib. *alaba hak) guztiz morfologizatu gabe, askoz zaharragoa izan daiteke eta EBZaren haustura baino lehenagokoa.

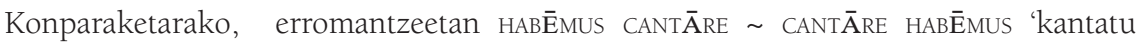
behar dugu' perifrasia /kantare emus/ hurrenkerarekin gramatikalizatu zen geroaldi bezala

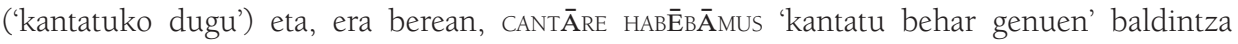
apodosi bezala, 'kantatuko genuke' esanahiarekin. Gramatikalizazio bera dugu hizkuntza erromantze gehienetan (Balkanetakoak eta Sardiniakoa alde batera utzita) eta, beraz, oso goiz abiatu zela pentsatu behar dugu. Dena den, bigarren osagaiaren askatasun morfologikoa denbora luzean mantendu zen (cf. adib, conbidar le yen de grado El Cid-en) eta, are gehiago, neurri batean orain arte mantendu da portugesez (cf. port. dir-te-ia).

Beraz, Mitxelenak "el plural se formó" esaten duen lekuan "el artículo plural se hizo afijo" edo honelako zerbait irakurri behar dugu, nire ustez, Manterolak (2015a) ondorioztatzen duen bezala.

\section{Euskararen fonologia diakronikoa eta EBZa}

Atal honetan saiatuko naiz zenbait fenomeno fonologikoren diakronia zehazten, EBZaren aurreko eta ondorengo gertakariak bereiziz posible den neurrian. Bi murriztapen eta bi bilakaera hartuko ditut kontuan.

\subsection{Murriztapen fonotaktikoak}

Denok dakigunez, euskal jatorriko hiztegian kontsonanteek oso banaketa asimetrikoa erakusten dute. Hitz erdian, bi bokalen artean afrikatuen eta frikarien arteko oposaketak (s/ts, $z / t z$ ) sendoak dira. Hitz hasieran, aldiz, bakarrik frikariak aurkitzen ditugu eta hitz bukaeran batez ere afrikatuak, salbuespen gutirekin. Era berean, bokalen artean herskari ahoskabe eta ahostunak oposaketa fonemikoan daude $(p / b, t / d, k / d)$, baina hitz hasieran bakarrik ahostunak aurkitzen ditugu. Mitxelenak datu hauekin batera mailegu zaharren egokitzapena (adib 
CORPUS > gorputz) eta txandaketa morfonologikoak (adib gari/gal-) kontuan hartuz, aintzineko euskararako bere sistema kontsonantiko orokor ezaguna proposatu zuen (Martinet-en 1950 hipotesia onartuz eta garatuz): erdian fortis vs lenis, hasieran lenis bakarrik eta bukaeran fortis bakarrik.

Zaila da jakitea noiz hasi ziren eta noiz arte iraun zuten murriztapen hauek. Garbi dago EBZa baino lehen sortu zirela, baina ziur asko murriztapen batzuk beste batzuk baino lehenago sortu eta galdu ziren. Beharbada, hitz-hasierako herskari ahoskabeen (edo bortitzen) kontrako murriztapena EBZa baino lehen ahuldu zen. Hitz-hasierako afrikatuen kontrako murriztapenak, aldiz, askoz gehiago iraun zuen, antza denez.

\subsubsection{Herskariak}

Herskariekin hasiz, Akitaniako testuetan herskari ahoskabeak aurkitzen ditugu hitz hasieran (CISON, TALSCONIS, etab., Gorrotxategi 1984). Interpretazio posible bat da hasierako ahoskabeen aurkako murriztapena ez zela oraindik sortu Akitaniako inskripzioen garaian.

Maileguek informazio zehatzagoa ematen digute ahostuntze arauaren ahalezko kronologiaz. Dakigunez mailegu zaharretan joera indartsu bat aurkitzen dugu hasierako herskariak ahostuntzeko. Dena den, itxuraz nahiko zahar diren mailegu batzuetan herskari ahoskabeak hitz hasieran aurkitzen ditugunez gero (kale, kare, kirru), ondorioztatu behar dugu murriztapen hau EBZa baino lehen galdu edo ahuldu zela.

Hasierako herskarien ahostuntzearen kronologia finkatzeko, Guiter-ek (1989) garrantzi berezia ematen dio tipula maileguari. Guiter-en ustez, hasierako horzkaria ulertzeko pentsatu behar dugu erdal iturriak $/ \mathrm{k}^{\mathrm{j}} /$ zuela euskarak hitza mailegatu zuen momentuan. Bere iritziz, /ke, ki/ sekuentzien bustidura III. mendean hasi zen (cf. baita ere Straka 1979[1956]: 201). Allen-ek (1978: 14), aldiz, ondorioztatzen $\mathrm{du} / \mathrm{k} / \mathrm{>} / \mathrm{t} /$ palatalizazioa, /e, o/ bokalen aurrean ez zela gertatu V. mendea baino lehenago, ordura arteko gramatikalari latindarrek ez baitute horrelako ahoskerarik aipatzen. Edozein kasutan, euskal hitzak daukan /t/ konsonantea errazago ulertzen da sorburu-hizkuntzan kontsonanteak ahoskune aurreratua bazeukan. Garrantzitsua dena da ez dela ahostuntzen. Dena den, Dipulatze leku-izena dugu (beharbada kipula, gipula aldaerak zaharragoak dira).

Akitaniako akitaniera (nolabait esateko) EBZaren arbaso zuzena balitz, eta testuetako hasierako ahoskabeak at face value interpretatuko bagenitu, oso leiho estua izanen genuke hitz-hasierako ahoskabeen kontrako murriztapen fonotaktikoa kokatzeko. Badirudi noizpait I. eta VI. mendeen artean ahostuntze araua sortu eta indargabetu zela, nahiz eta hitzez-hitzezko egokitzapen analogikoak oraintsu arte iraun.

Hitz elkartuetan herskari ahoskabeak aurkitzen ditugu bigarren osagaiaren hasieragunean, adib ustekabe. Arrazoia, kasu batzuetan behintzat, izan daiteke konposatua eratu zela murriztapena indarrean jarri baino lehen. Adibidez, ez dakit etimologia hau zuzena den, baina lat. canss hitzak gaitz emanen luke euskaraz, ezagutzen ditugun arau fonologiko 
diakronikoak aplikatuz. ${ }^{10}$ Esanahiaren aldetik ez dut oztoporik ikusten, cf. aqua et panis est vita canis; Clodianus canis (Cicero); edo esp. día de perros, vida perra, perra suerte, etab, ya canes traidores (El Cid). Jatorria hau izango balitz, espero dugun ahostuntzea dugu mailegu honetan. Edozein kasutan, beste aldetik, oso litekeena da mikaitz minkatz hitza konposatu bat izatea, osagai honekin bigarren lekuan, h.d., < *mi $\tilde{h} i+$ kaitz 'mihi gaitz'. Horrela bada, ahoskabea mantendu da bere horretan hitz erdian konposatuan. Hitz elkartuak, noski, forma libreak baino berriagoa izan behar du. ${ }^{11}$

\subsubsection{Txistukariak}

Hitz-hasierako tz-, ts- afrikatuen kontrako murriztapenak, aldiz, askoz bizi luzeagoa izan bide du, antza denez. Honetaz, maileguek eman diezaiguketen ebidentzia, hala ere, berriagoa da, latinak ez baitzeukan fonema afrikaturik. Mendebaldeko hizkuntza erromanikoek bi afrikatu horzkari garatu zituzten, ahoskabea /ts/ eta ahostuna /dz/, VI. edo VII. mendean. ${ }^{12}$ Fonema hauek bi sorburu nagusitatik datoz: alde batetik herskari belareetatik, /ke, ki/ > $\left[\mathrm{k}^{\mathrm{j} e}, \mathrm{k}^{\mathrm{ji}}\right]>/ \mathrm{f} \mathrm{fe}, \mathrm{t} \mathrm{fi} />/ \mathrm{tse}, \mathrm{tsi} /$ (CENTU $>$ ciento, BRACCHIU $>$ braço, DICIT $>$ dize, FACET $>$ faze), eta, bestetik, herskari horzkari + iod bilkuretatik (*APITIA > cabeça). Geroago, eta leku batzuetan besteetan baino lehenago, afrikatuek elementu herskaria galdu zuten. Gaztelaniaz, desafrikatze fenomeno hau XIII. mendean hasi zen, dirudienez, eta XV. mendean oraindik ez zen orokorra (Alonso 1955: 1. lib., 377-379, Lloyd 1987:333).

VII. eta XIII. mendeen artean euskarak erromantzeetatik hartu zituen mailegu guztietan /ts-/ > /s-/ egokitzapen araua aplikatu da sistematikoki, ez baitugu tz-afrikatuaz hasten diren mailegurik. Adibidez, itxura guztien arabera, zeru, zendea eta antzeko adibide batzuen iturriak/ts-/ zeukan: errom. /tselu/ > zeru, /tsentena/ > zendea. Esan bezala, erdal hitz hauetan /ke/ > /tse/ bilakaera (tarteko urratsekin) VII. mendekoa edo denez, maileguak

10. Hala ere, Julen Manterolak esaten didanez, etimologia hau izango balitz, espero genuke *gahitz aurkitzea nonbait; baina forma hau ez da lekukotzen.

11. Bestaldetik, ekaitz bezalako hitz batean, ${ }^{*} e g u+$ gaitz (edo $*$ egu + kaitz) konposatu batetik baldin badator, testuinguruak esplikatzen du ahoskabea: ${ }^{*} e g(u)+$ gaitz > *etgaitz > ekaitz.

12. Esan dugunez, belarren palatalizazioa V. mendean edo gertatu zen; ikerlari batzuentzat, lehenago, III. mendean. Mendebaldeko erromantzeetan hurrengo pausua $/ \mathrm{f} />/ \mathrm{ts} /$ bilakaera dugu. Ez dakigu prezeski noiz gertatu zen bigarren soinu aldaketa hau; eta ziur asko leku batzuetan beste batzuetan baino askoz beranduago gertatu zen. Edozein kasutan, Galian eta Rhaetian, /ka/ sekuentziaren palatalizatzea baino lehenago gertatu zen. Bestela frantsesez CENTU eta CANTŌ hitzek, adibidez, kontsonante berbera izango lukete gaur, eta ez da horrela (fr cent vs chante). Badirudi Rhaetian eta Galiako parte batean eman zen $/ \mathrm{ka} />/ \mathrm{f}$ a/ aldaketa X. mendea baino lehenago gertatu zela (Price 1984:30). Straka-k (1979[1956]: 203), askoz goizago kokatzen du, V. mendean. 
ez dira zaharragoak. ${ }^{13}$

Badugu, hala ere, ulertzeko hain erraza ez den arazo bat hemen. Bokalen artean, z/ tz oposaketa sendoa da euskaraz eta espero genuke erromantzearen bokalen arteko /-ts-/ eta /-dz-/ afrikatuek euskal afrikatu horzkaria izatea ispilu. Baina, egia esan, oso mailegu gutitan aurkitzen dugu -tz-euskaraz: gurutze (beharbada erronk. krutxe mailegu zaharragoa da, itxuren kontra), zerbitzu, erronk. platza ( plazta, ikus Estornés Lasa 1997), eta...?

Putzu hitzean ere afrikatua dugu, baina beharbada hitz honen afrikatua geminatua zen gaztelaniaz edo sorburuko erromantzean, h.d. /poddzu/14. Hau pentsatzeko arrazoi bat da hizkera judeo-espainol batzuetan (baina ez guztietan) hitz honek /dz/ (edo >/d $/$ ) duela, salbuespen bezala, nahiz eta normalean desafrikazioa orokorra izan hizkera horietan, 2. atalean ikusi dugun bezala (Quintana 2006). Bestalde, Lapurdi-Behenafarroetan dotzena aurkitzen badugu ere (cf. gask. dotzena), dozena hedatuagoa da. Judeo-espainolean afrikatua orokorra da dotze, tretze zenbakietan (katalanez bezala) eta beraz, badirudi hemen ere afrikatua geminatua zela ertaroko gaztelanian eta inguruko erromantzeetan.

Zergatik hain mailegu guti bokalen arteko -tz- afrikatuarekin, afrikatua gutienez XIII. mendera arte mantendu bazen gaztelaniaz eta inguruko beste erromantzeetan? Zergatik ez dugu, adibidez, *arratzoi, *natzio? Eta, hitz bukaeran, zergatik erraz < gazt. /raets/? ${ }^{15}$ Honetarako ez dut azalpenik ikusten.

\subsection{Bokalen arteko sudurkarien galera}

Morfema-egiturako murriztapenak alde batera utzita, Mitxelenak identifikatzen dituen arau fonologiko diakronikoak ez dira hainbeste. Lakarrak (2011) hamabost arau zerrendatzen ditu. Garrantzitsuen artean bokalen arteko /n/-aren galera dugu. Antzeko gertaera bat gaskoiaren fonologia diakronikoan ere aurkitzen dugu (baita galaiko-portugesarenean ere).

Sudurkariaren galera, hau da, /n/ > 0, ez zen bat-batean gertatu. Gaskoierarako, Chambon \& Greub-ek (2002: 477) pentsatzen dute komeni dela lau etapa desberdin bereiztea. Euskararako ere (cf. Lakarra 2011: 194), antzeko modu batean (baina ez guztiz paraleloki, gaskoieraz hasperenketa ez baitzen sortu ingurune honetan) (5)en zehazten diren urratsak bereiz ditzakegu (cf. Igartua 2015 konparaketarako). Lehen pausua, /n/-aren mihi-puntako kontaktua ahultzea zen, /h/ sortuz. Hortik aurrera, badirudi / $\tilde{\mathrm{h}} /$ sudurkariak bi bilakaera

13. Hemendik ondorioak atera ditzakegu mailegu hauek erakusten dituzten beste aldankutzak ere (-l- > -r-, sudurkariaren galera) datatzeko, neurri batean behintzat. Ez dakigu, adibidez, -l- > $-r$ - araua noiz sortu zen, baina badakigu arauak ez zuela bere indarra galdu zeru hitza mailegatu baino lehen (ikus 6. atalean, zendea vs bentana).

14. Mailegu honetaz, ikus Manterola (2015b).

15. Ekialdean errats, erretx aldaerak aurkitzen dira (ikus OEH). 
desberdin izan zituela. Hizkera batzuetan hala nola bizkaiera zaharrean eta erronkarieraz, hasperenketa galdu zen bokal sudurkari fonemikoak sortuz. Beste leku batzuetan (LapurdiBehenafarroetan), ezaugarri sudurkaria galdu zen hasperenketan, / $/ \tilde{h} /$ eta $/ \mathrm{h} /$ fonemen arteko neutralizazioa eraginez.

(5) Hasperenketa sudurkariaren bilakabidea

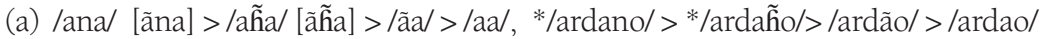

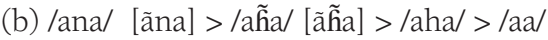

Portugesez ere gertatu zen bezala, hersketa sudurkari palatala berripini zen /i/ baten

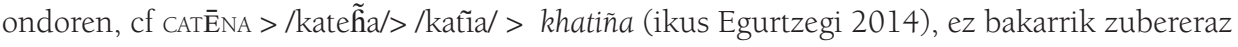
(Mitxelena 1985: 303). Era berean, hizkera batzuetan kontsonantea berripini da hitz bukaerako diptongoetan: *arrani > *arrã > arraiñ; GRANU > *garãu > garaun.

Prozesua orokorra denez euskaraz, bere hasiera —baina hasiera besterik ez- EBZa baino lehenagoko garai batean kokatu behar dugu. Metodo konparatiboaren bidez, bokal sudurkariak berreraiki ditzakegu, baina ez kontsonante hobikaria, cf adib. ardao, ardo, arno, $\operatorname{ard} \tilde{u}<$ EBZ * $\operatorname{ard} \tilde{a} \tilde{o} .{ }^{16}$ Zubereraz hasperenketa mantendu den hitzetan, EBZrako ere berreraiki

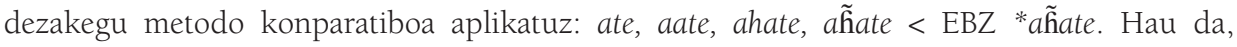

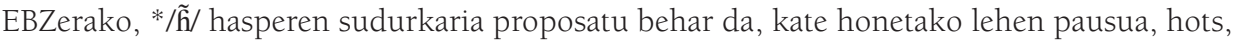
/ana/ > /ẫa/ EBZa hautsi baino lehenagoko garai batean gertatu zelarik.

Leku-izen askotan euskaraz galdu den sudurkaria aurkitzen da orain arteko erdal izen ofizialetan. Honek erakusten du galera ez dela hain zaharra: Fruiz/Frúniz, Aramaio/Aramayona, Artaxoa/Artajona, Zestoa/Cestona, etab. Bestaldetik, RS errefrau bilduman Aramayo dabenac ez lemayo / A Aramayona quien la tiene no la daria esaera aurkitzen dugunez, ondorioztatu behar dugu toponimo honek behintzat XV. mendea baino lehen guztiz galdua zuela kontsonantea euskaraz, baina galera ez zela askoz zaharragoa. Datu guzti hauek esplikatzeko ere, badirudi

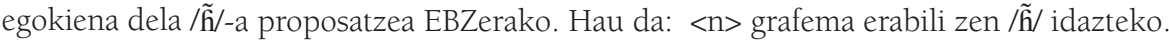

Izenordain zehaztugabeetan daukagun aldakortasuna ere badirudi ongi esplikatzen

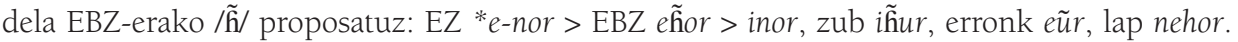
Lenizio kate honetako lehen pausua, mihi-puntako hersketaren galera, EBZa baino lehen gertatu zen. Beste pausu guztiak EBZaren batasuna hautsi ondoren eman ziren.

Lehen begiratu batean, irudiko luke Nafarroako izain (< izanen), errain, emain (eta Arbizuko esaan 'esanen', etab.) bezalako geroaldiko partizipioek ere sorburu berbera dutela. Hala ere, gertakarien lehendabiziko eta azken urratsak berdinak badira ere, hots, /n/ >0 N__V, ziur aski fenomeno hau modernoagoa da eta tarteko urratsak ere desberdinak izan dira. Caminok (2013: 112) gogorarazten digunez, Lapurdiko testu zahar batzuetan, egoren, izaren,

16. arno aldaera/d/-aren sudurkarizatzearen bidez esplika daiteke (edo, beharbada, sinkopaz). 
emaren, etab., aurkitzen ditugu. Beharbada, beraz, kasu honetan disimilazio bat dugu lehen urrats bezala, /n/-a galdu den eskualdean ere, edo Ohala-ren (1993) teorian, hiperzuzenketa: /emanen/ [emãnẽn] > /emaren/ (> /emaen/ > /emain/), cf. baita ere arima.

\subsection{Hitz-hasierako ioda}

Euskaraz hitz-hasierako <j->ren banaketa oso murriztua da, maileguak alde batera uzten baditugu. Ia kontsonante hau duten hitz guztiak aditzak dira: jan, joan, jakin, jardun, jarraitu, etab., salbuespen guti batzuekin: jaun, jabe, jatorri, jainko, jai. (Ziur asko, hauetariko batzuk edo agian guztiak aditzetatik datoz, cf. Lakarra 2006). Hitz hauen bigarren alderdi aipagarria haien ahoskeran aurkitzen dugun aniztasuna da, noski: jan [jan] $\sim$ [jan] $\sim$ [ban] $[$ zan $] \sim[$ Jan $] \sim[$ zan $]$.

Aditzen morfologiak argi uzten du aditzetan behintzat kontsonantearen azken jatorria /e/ bokala dela, adib. */e-an/ > /jan/ (Mitxelena 1975: 119, 168). Horretaz gain, Goizuetako hizkeran aditz hauek daukaten azentuera bereziak, lehen silaban, erakusten digu hasierako sekuentzia heterosilabikoa zela azentua bigarren silaban finkatu zen garaian: (e)sán, (e)mán, artú, autsí, (i)kúsi vs yákin ( <*e.ákin edo *i.ákin), yárri, yósi, etab. (Hualde 2008: 210). Badirudi, beraz, EBZerako *ea- (*eo-, etab) proposatu dezakegula, beste aldaketa guztiak, */ea-/ > /ja-/ barne, EBZa baino berriagoak direlarik. Gaurregungo euskaran aurkitzen ditugun aldaerak esplikatzeko hurrengo aldakuntza ordenatuak proposatu behar ditugu, beraz:

(6) Hitz-hasierako /j/-ren bilakaeraren urratsak

1. Irristariaren indartzea: $/ \mathrm{j}-/>/ \mathrm{j} / \sim / \mathrm{d} / \sim / 3 /$

2. Frikariaren ahoskabetzea: $/ 3 />/ \delta /$

3. Ahoskunearen atzeratzea: $/ \int-1>/ \chi-1$

Goazen pausoz pauso.

\subsubsection{Irristariaren indartzea: $/ \mathrm{j}-/>/ \mathrm{d} / \sim / 3 /$}

Printzipioz, hipotesi bezala, onar dezakegu gaurregun $/ 3^{-} /$, / $/$- eta / $\chi$-/ kontsonanteak ditugun eskualde guztietan gertatu zela hitz-hasierako indartze hau, lehenago edo beranduago, $/ \int-/$ eta / $\chi$-/ kontsonanteek lehenagoko /3-/ bat islatzen baitute.

Hiru aldakuntza hauetariko bakoitzaren geografia historikoa zehaztea testuen bidez ez da beti erraza, batez ere $<j>$ grafiak duen anbiguotasunagatik. Donemiliagako glosetan, adibidez, garbi da <jzioqui > hitzaren lehen fonema /i/ dela, baina zer dugu <ajutu >-ren erdian? Nola irakurri behar, /ajutu/, /adbutu/, ala /azutu/? ${ }^{17}$ Mitxelenak (1985: 171) ohartarazi bezala,

17. Testu berean agertzen zaigun erromantzezko <aiutorio> formak anbiguotasun bera du, cf gazt. ayuda, kat. ajut. 
Etxeparek geynco eta ieynco, gin, etab. idazten duenez, badirudi bere hizkeran hitz-hasierako irristari etimologikoak ahoskera indartua zuela, nahiz eta ez den posible jakitea fonema hau /y/, /\$b/ edo /3/ ahoskatzen zen. ${ }^{18}$

Gaurko datu geografikoak erabiliz, badirudi irristari palatalaren indartze edo gogorketa $(/ \mathrm{j}-/>/ \mathrm{f} / \sim / \mathrm{d} / \sim / 3 /)$ bi eremu desberdinetan gertatu zela, beharbada garai desberdinetan: alde batetik, ia erdialde eta mendebalde osoan (Gipuzkoan, Bizkaiko zati handi batean, Araban eta Nafarroako hego-mendebaldean) eta, bestetik, Pirineoetako hizkeretan, mugaren bi alderdietan (Zuberoan, Erronkarin, Zaraitzun, Aezkoan eta inguruko eskualde batzuetan) (ikus Mitxelena 1985: 170). Aldiz, antza denez, hasierako /j-/ irristariak bere horretan iraun du, indartu gabe, orain arte Bizkaiko mendebaldean (Txorierri, Arratia), Lapurdin eta Nafarroako iparrean (Bortziriak, Baztan).

Aurresabaikari ahostuna gaur arte mantendu duten hizkeren artean, bi patroi fonetiko aurkitzen ditugu. Lekeition, Bermeon (eta beharbada /3/ kontsonantea duten Bizkaiko beste hizkera guztietan) bi alofono aurkitzen ditugu, afrikatua eta frikaria, testuinguruaren arabera, adib. [b] an dau vs sagarra [3] an dau (cf kat [\$] ent, la [3] ent 'jende, jendea'. Badirudi gaztelania zaharrak ere alofonia hori zeukala). Aldiz, zubereraz frikaria dugu testuinguru guztietan (frantsesez bezala).

Hitz-hasierako (eta silaba-hasierako) irristarien gogorketa bilakaera arrunta da. Indartze honen bidez, silaba egitura hobetzen da nolabait. Erromantze askotan, adibidez, sistematikoki aplikatu zen indartze araua (frantsesez, italieraz, portugesez, etab.). Gaztelaniaz, aldiz, ez zen hain sistematikoki aplikatu; cf., adib. IANUĀRIU > fr. janvier, it. gennaio, port. janeiro vs gazt. enero; IAM > fr. déjà, it. già, port. já vs gazt. ya, etab. ${ }^{19}$ Gaztelaniaz hitz-hasierako irristaria /o/ edo / $\mathrm{d} /$ baten aurretik bakarrik indartu zen sistematikoki baina kontestu honetan ere aurkitzen ditugu salbuespenak: junto, jugar vs yunta, yugo. Beraz, euskararen garapen honetarako kanpotiko eragina bilatzekotan, gaztelania ez litzateke eragin-sorbururik garbiena. Gaskoieraz gertakaria orokorragoa da. Badirudi nafar-aragoieraz ere gaztelaniaz baino orokorkiago indartu zela hasierako ioda. ${ }^{20}$

Beharbada Bizkaiko zati batean garapen biribila eman zen: $/ \mathrm{j}-/>/ 3-/>/ j-/$, ikus Hualde (2002: 157). Txorierrin erabiltzen den koiu 'hartu' bezalako hitz bat azaltzeko badira bi posibilitate. Litekeena da, mailegua gaztelaniatik etorri beharrean, $\mathrm{L} J>/ j$ / bilakaera izan zuen hizkuntza batetik hartu zela, cf. ast-leon. coyer, muyer, trabayu vs gazt. coger, mujer, trabajo (LJ

18. Gaurregun, hala ere, irristaria dugu hitz hauetan behenafarreraz, I. Caminok esaten didanez.

19. Kasu batzuetan, indartze arauaren aplikazio irregularrak hitz pareak sortu ditu azken hizkuntza honetan, hala nola yunta vs junta.

20. Datu anekdotikoak emateko, Erronkariko erdaraz, juada (= gazt. yugada), ginebro (= gazt. enebro), etab. erabiltzen ziren. Gipuzkeraren jela hitza ere gaztelania ez den beste erdara batetik dator. 
$>/ 3 /$ ). Beste posibilitatea da eskualde honetan $/ 3 />/ j /$ gertatu dela. Bigarren hipotesi honen bidez bakarrik esplika dezakegu yárra (< gazt. jarra). Hipotesi honen indargarri, cf. Leioal Lejona, Loiu/Lujua, Buia/Bujana. Oraintsu arteko aldaera ofizialak ulertzeko /3/ bat behar dugu izen hauetan. Bestaldetik, Lekeitioko /kozidu/ 'sareak bildu' hitzean gaztelania zaharraren sabaiaurreko frikari ahostuna gorde da. ${ }^{21}$

\subsubsection{Frikariaren ahoskabetzea: /3/ > / /}

Gaurregun /3/ kontsonantea bi eremutan bakarrik aurkitzen dugu. Alde batetik, Zuberoan eta beste aldetik Bizkaiko zenbait alderditan. Aldiz, /3/ sabaiaurreko kontsonante ahostuna garatu zutèn hizkera gehienetan ahoskabetze arau bat eman zen beranduago, bai erdialdeko eskualdean, baita garai batean /3/ fonema zuten Nafarroako Pirineoetako hizkeretan ere (aezkera/zaraitzera/erronkariera). Pentsa daiteke /3/-ren ahoskabetzea gaztelaniaren eraginagatik gertatu zela. Baina guztiz posible da, era berean, euskararen eraginagatik gaztelanian gertatzea, euskararen eremu osoan ahoskabetzea ez gertatu arren. Dakiguna da eremu erromanikoan gertaera Gaztelako iparraldean hasi zela. Fenomenoa orokorragoa zen hizkuntza honetan, /z/, /dz/ eta /3/ kontsonanteek pairatu baitzuten. Hizkuntza erromanikoen artean, txistukarien ahoskabetzea gaztelaniaz eta gaztelaniaren eragin zuzena izan duten hizkeretan gertatu da soilik (galiziera, astur-leonera, nafar-aragoiera, eta Valentziako katalanaren zati batean). Beste hizkuntza erromaniko guztiek (hala nola portugesak, katalanak, frantsesak, italierak eta errumanierak) mantendu dituzte erdiaroko frikari ahostunak orain arte.

Noiz gertatu zen /3/-ren ahoskabetzea, bada? Gaztelania dela-ta, goian ikusi dugu judeo-espainolak /z/ frikari ahostuna gorde duela. Sabaiaurrekoekin ere eutsi zaio ahostun/ ahoskabe kontrasteari hizkuntza honetan, cf. /izo/, / $\mathrm{Gente} / 22$ vs /difo/. Honek erakusten du gaztelaniaz 1492 urtean, ahoskabetzea ez zela ahoskerarik hedatuena. Urte batzuk beranduago, XVI. mendean, Burgosen /Sugar/ esaten zen, ahoskera ahoskabetuaz, baina Toledon oraindik ere /zugar/, Fray Juan de Córdovak (1578) esaten digunez (Cf. Alonso 1969: 23)

XVI. mendeko testuetan, batez ere erabilera "gurutzatuek" ematen digute ebidentzia ahoskabetzearen hedaduraz. Gaztelako Alfontso X.ak zabaldu zuen ortografian /// ahoskabea $<x>-z$ idazten zenez, sabaiaurreko frikari ahoskabea, alde batetik, eta frikari/afrikatu ahostuna, bestetik, behintzat, ondo bereizten ziren, adib dixo/difo/vs fijo /hizo/. Beranduagoko momentu batean, hala ere, txistukarien gorketa hasten da Gaztelako iparraldean eta grafiak hasten dira

21. Uribe-Kostako yaboi aldaerak (Gilisasti 2003) analogikoa dirudi; hau da, hizkuntzen arteko egokitzapen arau edo korrespondentzia baten ondorioa da (cf. 6. atala); hitz honek ez baitu inoiz izan /3-/ edo /j-/ fonemarik inongo erromantzetan (SAPŌNE $>$ gazt. /sabon/ eta gero $>$ /Sabon/, hizkuntza honetan XV. mendean eman zen /s/ eta /S/ fonemen arteko nahasketa esporadikoaz; cf. fr savon, kat sabó, port sabão).

22. Hizkuntza honetan /3/ zaharraren alofono frikaria eta afrikatua bi fonema desberdin bihurtu dira. 
txandaka erabiltzen, etimologia edo grafia zaharra errespetatu gabe. ${ }^{23}$

Euskarara etorriz, irudiko luke erabilera gurutzatuez ere baliatu gaitezkeela ahoskabetzearen garapen diakronikoa eta hedadura geografikoa zehazteko. RS-etan <gajpaga>, dudarik gabe /gaSpaga/ 'gaitz gabe', aurkitzen dugunez, garbi dago autore anonimoarentzat $<j>$ eta $<x>$ hizkiak fonetikoki baliokideak zirela, sabaiaurreko frikari ahoskabea adierazteko. Modu berean, Mikoletak <xauna $>$, <xausi $>$, <xossi $>$, <xo $>$ eta $<$ jarri $>$ idazten duenez, garbi dago $<j>$ eta $<\mathrm{x}>$ balio fonetiko berberarekin erabiltzen dituela, sabaiaurreko frikari ahoskabe bat /S/ adierazteko, hain zuzen. (Nafarroako XVII. mendeko egoerarako, ikus Mitxelena 1985: 171).

Baina gauzak ez dira hain garbiak. Momentu batetik aurrera, /3/ fonema galdu ondoren, Burgos aldeko gaztelaniadunentzat $<j>($ edo $<-\mathrm{i}->),<\mathrm{g}(\mathrm{i}, \mathrm{e})>$, eta baita $<-\mathrm{x}->$ ere erabil zitezkeen fonema berbera adierazteko, hots, / $/$. Hau da Lazarragak eta RS-en egile anonimoak, adibidez, erabiltzen duten ortografia. Guztiz posible izango litzateke ortografia honetaz baliatzen den euskal idazle batek euskaraz /S/ eta /3/ bereiztea, baina izkribuz adierazteko bide garbirik ez izatea. Konparaziorako, hau da aurkitzen duguna garai honetan frikari eta afrikatu horzkariekin. Kasu honetan badakigu bi fonema desberdin ditugula, adib /isan/ vs /etsan/, baina gaztelaniatik hartutako ortografiak ez zeukan biderik kontraste hau adierazteko.

Axularrek (2015 [1643]:10) esaten digu batzuek igilic 'ixilik', gedea 'xedea', lajoa 'laxoa' idazten zutela. Villasantek bere edizioaren ohar batean gehitzen duenaren arabera, badirudi Materrek sartu zuela idazkera hori Lapurdiko eskolan (ikus Ariztimuño et alii 2015). Lapurtera klasikoan ez zegoen /3/ fonemarik eta beharbada Materrek hegoaldeko izkribuetatik hartu zuen ohitura grafiko hau / $/$ fonema adierazteko, orduko frantsesaren ortografian ez baitzegoen horrelakorik (ikus Beaulieux 1967, Baddeley 1993). ${ }^{24}$ Honek guztiak gauzak korapilatzen ditu ahoskabetzearen kronologia eta geografia zehazteko.

Aragoieraz hitz-hasierako prepalatalak afrikatu bihurtu ziren testuinguru sintaktiko guztietan - 5.3.1 atalean aipatu genuen alofonia deseginez- (cf. arag. chunta, gazt. junta; arag. chen, gazt. gente, etab.), ez dago garbi ahostuna ahoskabetu baino lehen (adib. /la zunta/ $>$ /la çunta/ > /la tfunta/), edo alderantziz. Hizkuntza hau izan daiteke eusk. txarro, txertatu eta antzeko maileguen sorburua. Dena den, euskal hitzetan ere $/ \mathrm{f}-/>/ \mathrm{t} f-/$ aurkitzen dugunez gero, badirudi euskaraz edo euskal hizkera batzuetan ere jazo zela gertakari hau, hurrengo azpi-atalean azaltzen dugun gertakaria baino lehen.

23. Hala nola Diego Hurtado de Mendoza-ren (1367-1404) honako bertso ezagunean "A aquel arbol que mueve la foxa", non etimologiak eta lehenagoko grafiak foja eskatzen duen.

24. Beharbada Materren belarrietara euskararen eta frantsesaren / $/$ fonemak ez ziren guztiz berdinak eta horregatik ez zuen erabili <ch> grafia euskal fonema hau adierazteko. Kontuan hartu behar da, beste aldetik, <x> grafiak balio guztiz desberdin bat zuela frantsesez. 


\subsubsection{Ahoskunearen atzeratzea: $/ \delta />|\chi|$}

Gaztelaniaz sabaiaurreko frikari ahoskabea hasi zen ahoskunea atzeratzen XVII. mendean edo; beharbada lehenago Andaluzian. ${ }^{25}$ Cervantes-ek Don Quixote argitaratu zuenean (1605ean) oraindik ere / / sabaiaurrekoa izan bide zen prestigiozko ahoskera, nobelaren izenburua frantsesez eta italieraz Quichotte, Chischotto bezala, hurrenez hurren, egokitu baitzen (Penny 2002:101). XVII. mendean zehar, hala ere, berrikuntza hedatu zen gaztelanian ahoskera zaharra guztiz desagertu arte.

Ibero-erromanikoaren eremuan, azpimarragarria da soinu aldaketa honek hizkuntza muga zaharrak erabat errespetatu zituela. Alde batetik, gaztelaniaren eremu osora hedatu zen, bai Espainian, baita Latinamerikan ere. Bestaldetik, gaztelaniaren alboko hizkuntza erromanikoetan saibaiurreko frikariaren ahoskune-atzeratzea ez zen inoiz hedatu, eta /S/ fonema oraindik ere galegoz, asturieraz eta aragoieraz gordetzen da. Euskal Herrian, oso laster zabaldu zen $/ \delta />/ \chi /$ soinu aldaketa, XVIII. mendearen hasierarako hedatua baitzegoen Gipuzkoan (Mitxelena 1985: 171-172).

Badira arrazoi sendoak pentsatzeko gertaera gaztelaniatik iragan zela euskarara. Arrazoi nagusia da $/ S />/ \chi /$ aldakuntzak salbuespenak dituela euskaraz. Gipuzkoan / $/$ soinuak iraun du balio adierazgarraria duen hitzetan: xexen, xagu, goxo, gaixo gajo (Mitxelena 1985: 191; ikus Trask 1997: 156-157). Egoera hau deigarria da, Neogramatikoen irakaspenen aurka baitoa. Hau errazago azaltzen da kanpotik "inportatutako" aldakutza baldin bada euskaraz. Beharbada ahoskera berria maileguekin hasi zen eta handik hedatu zen beste hitzetara.

Aezkoa, Zaraitzu eta Erronkariko hizkeratan, berriz, $/ / />/ \chi /$ aldakuntza ez zen gertatu, jaun eta jainko hitzak eta maileguak alde batera utzita (erronk jein / xein/ baina xin / $\mathrm{Sin} /$, xan /San/, xakin /Sakin/).

Mitxelenak (1985: 170) orriazpiko ohar batean oso datu interesgarri bat ematen digu: XX. mendeko erdialdean $/ \delta-/>/ \chi-/$ bilakaera oraindik hedatzen ari zen Uharte-Arakilen eta inguruko herrietan. Badirudi beraz soinu aldakuntza honek 250 urte edo gehiagoko bizitza izan duela, hizkuntzan sortu zen momentutik.

\subsection{4. /3/ berriagoak}

Bizkaieraz edo mendebaldeko euskalkian (Zuazoren 2010, 2014 sailkapenean) /3/ fonema hiru testuinguru desberdinetan sortu da, hiru momentu desberdinetan, mendebaldeko mutur-hizkeretara inoiz hedatu gabe. Frikari honen ahoskabetzea birritan behintzat gertatu da.

25. Zaila da jakitea soinu aldaketa noiz hasi eta nola hedatu zen gaztelanian, kasu honetan ortografiak ez baitu askorik laguntzen (ikus Sánchez Méndez 2013: 585-586). 
Orain arte ikusi dugun prozesuaz gain, berrikiago */dj-/ taldeak/3/ eman zuen nor-nori formetan (/zat/, /3ako/) eta hitanoan (/3ok/). Are beranduago, Bizkai-Gipuzkoetako zati handi batean/i_V/ingurunean kontsonante epentetiko bat sortu zen. Kontsonante epentetikoa/j/ edo /y/sabaikaria da Gipuzkoako ekialdean eta Nafarroako zenbait hizkeratan, eta aurresaibaikaria /3/, /S/ mendebaldean, kontsonante sabaikari eta aurresabaikarien arteko isoglosa Azpeitiaren (/mendije/) eta Azkoitiaren (/mendife/) artetik pasatzen delarik.

Hiru testuinguruak identifikatzeko jan, jako eta mendia adibideak erabiliko ditut:

$$
\begin{aligned}
& \text { /3/ren sorburuak mendebaldean } \\
& \text { *ea- > za /zan/ } \\
& \text { *dja- > za/zako/ } \\
& \text { *-ia > iza /mendiza/ }
\end{aligned}
$$

Gaurregungo hizkeretan hurrengo banaketak aurkitzen ditugu:

$$
\text { jan, jako, mendia mendebaldeko zenbait hizkeratan }
$$

$\begin{array}{llll}\text { Lekeitio } & \text { zan } & \text { zako } & \text { mendiza } \\ \text { Gernika } & \chi_{\text {an }} & \text { zako } & \text { mendize } \\ \text { Markina } & \chi_{\text {an }} & \text { xako } & \text { mendife } \\ \text { Oñati } & \chi \text { an } & \text { Sako } & \text { mendifa }\end{array}$

Lekeition (eta Bermeon) /3/guztiak beren horretan gelditu dira, beste aldakuntzarik pairatu gabe. Beste hizkeretan ahoskabetze eta ahoskune-atzeratze prozesuak ditugu.

Garbi dago soinu aldeketen hurrenkera desberdina izan dela eskualde desberdinetan. Markinan (edo Eibarren) jako saileko formetan ahoskabetzea Gernikan edo Oñatin baino lehenago gertatu zen, hitz hauek XVII. mendeko /S/> $/ \chi /$ aldakuntza jaso baitzuten. Aldiz /mendia/ > /mendiza/ bilakaera modernoago da. Juan Antonio Mogelek guztija idazten

\begin{tabular}{|c|c|c|c|}
\hline Markina: < 1500 & 3 an & zako & mendia \\
\hline$\sim 1600 / 3 />/ S /$ & San & Sako & mendia \\
\hline$\sim 1700 / S />\mid \chi /$ & xan & xako & mendia \\
\hline 1800 /ia/ > /iza/ & xan & xako & mendiza \\
\hline$\sim 1900 / 3 />/ S /$ & xan & 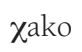 & mendife \\
\hline
\end{tabular}
duenez, badakigu epentesia 1800 urtea baino lehenago gertatu zela Markinan. Rollo-k (1925) aldiz /S/ ahoskabea deskribatzen du testuinguru honetan. Beraz /iza/ > /ifa/ aldakuntza XIX. mendean eman zen Markinan.

(9) /3/ren garapen historikoa Markinan 
Gernikako datuak esplikatzeko, onartu behar dugu/zan/ > / Jan/ gertatu zenean, oraingo beste /3/-ak ez zirela oraindik garatu. Beharbada lehen garai batean */dj-/ taldeak /d/ eman zuen, eta arrazoi honegatik kontsonante hau ez zen ahoskabetu, /3/-ren ahoskabetzea gertatu zenean:

(10) /3/ren garapen historikoa Gernikan

\begin{tabular}{|c|c|c|c|}
\hline Gernika: < 1500 & 3an & djako & mendia \\
\hline$\sim 1600 / 3 />/ S /$ & San & djako $\sim$ Gako & mendia \\
\hline$\sim 1700 / S />|\chi|$ & $\chi_{\text {an }}$ & cako & mendia \\
\hline 1800 /ia/ > /iza/ & $\chi$ an & 3ako & mendiza \\
\hline
\end{tabular}

Oñatin ere antzeko bilakabide bat dugu, baina, Markinan bezala, bigarren ahoskabetze bat jazo zen:

(11) /3/ren garapen historikoa Oñatin

\begin{tabular}{|c|c|c|c|}
\hline Oñati: < 1500 & $3 a n$ & djako & mendia \\
\hline$\sim 1600 / 3 />/ S /$ & San & djako $\sim$ bako & mendia \\
\hline$\sim 1700 / S />|\chi|$ & $\chi^{\text {an }}$ & bako & mendia \\
\hline 1800 /ia/ > /iza/ & $\chi^{\text {an }}$ & zako & mendiza \\
\hline$\sim 1900 / 3 />/ S /$ & $\chi$ an & Sako & mendifa \\
\hline
\end{tabular}

Datu hauek erakusten digute soinu aldaketen hurrenkera desberdina izan dela eskualde desberdinetan.

\section{Egokitzapen arauak eta kronologia erlatiboa}

Ikusi dugunez, eta Mitxelenak erakutsi zuen bezala, maileguen tratamenduak informazio garrantzitsua eman diezaguke prozesu fonologikoen kronologia interpretatzeko. Adibidez, zendea (</tsentena/, ez VII. mendea baino zaharragoa) eta bentana (Lazarragarengan) konparatuz, jakin dezakegu, hein batean, sudurkariaren ahultzea eta /nt/ > /nd/ araua noiz zeuden bizirik eta noiz ahuldu ziren. (Jakin dezakeguna da ez zirela indargabetu zendea mailegatu baino lehen, baina bai mendebaldeko euskarak bentana hitza hartu zuenerako. Datu hauekin bakarrik, ezin jakin noiz sortu ziren arauok.)

Badago, hala ere, arazo bat arau fonologikoen bizitza datatzeko maileguen laguntzarekin. Arazoa da euskarak garatu dituela korrespondentzia arau batzuk maileguak egokitzeko, honela mailegu berriei zahar itxura emanez batzuetan. Esate baterako, dakigunez, baloi hitza oso mailegu berria izan daiteke. Baina azaleko itxuren arabera *balone $>$ *balohe > balõẽ > baloi eboluzioaren ondorioa izan beharko luke. Ez da esan behar, ziur asko ez dela horrela izan. Aldiz, gertatzen dena da mendebalde eta erdialdeko euskalkietan gazt -ón $\rightarrow$ eusk 
-oi korrespondentzia arau bat sortu dela bukaera hau daukaten erdarazko hitzak egokitzeko (Hualde 1993, Oñederra 2009). Hau da, -oi bukaera duten mailegu guztiak, ezta gehienak ere, ez datoz -one bukaeradun erdal iturri batetik, bokal-arteko sudurariaren galeraren bidez. Guztiz alderantziz, mota honetako hitz gehienak -ón modernoago batetik egokitu dira korrespondentzia arau bat aplikatuz.

Hizkuntza estandarrean bizirik dagoen beste mailegu-egokitzapen arau baten arabera, gaztelaniaren hitz-bukareko /-o/ $\rightarrow$ eusk. /-u/; hala nola, gazt. texto $\rightarrow$ eusk. testu, elemento $\rightarrow$ elementu, artículo $\rightarrow$ artikulu eta antzeko adibide askotan. Araua mailegu berri askori aplikatzen bazaie ere, bukaera hau daramaten mailegu guztiek ez dute pairatzen, ikus adib. gazt. disco $\rightarrow$ eusk. disko, histórico $\rightarrow$ historiko, socialismo $\rightarrow$ sozialismo, etab.

Argi dago egokitzapen arau honek ez duela justifikazio fonologikorik, euskarak bi bokalak onartzen baititu hitz bukaeran: /-o/ bokala /-u/ bezain onargarria da. Baditugu, adibidez, buru eta bero, esku eta asko. Aldiz, bistan da arauaren aplikazioaren azpian patroi analogikoak ditugula, batzuetan morfemen arteko korrespondentziak (clasific-ado $\rightarrow$ klasifikatu, renaci-miento $\rightarrow$ ernazi-mendu) eta beste batzutan, besterik gabe, hitz-akabuko fonema sekuentziaren arabera, eratorpen atzizkirik ez badugu ere (Hualde 1991). Hizkuntza estandarraren egokitzapen arau hau literatur tradizioan eta ahozko hizkeretan oinarritzen da euskal hizkera guztietan adostasun osorik ez badago ere arauaren esparrua zehazteko orduan (ikus Irigoien 1984).

Hizkera batzuetan oso patroi analogiko interesgarriak aurkitzen ditugu (edo genituen). Adibidez, Busturialdeko hizkera batzuetan gazt. /-ero/ $\rightarrow$ /eru/ (azentugabea) dugu erreferentea pertsona bat denean, hala nola, frutero $\rightarrow$ fruteru, artikuluarekin fruterue 'fruta-saltzailea' baina gazt. /-ero/ $\rightarrow$ léro/ (azentuduna), erreferentea ontzi edo leku bat denean, frutero $\rightarrow$ frutéro, frutéroa 'fruta -ontzia' ${ }^{26} \mathrm{Bada}$, auzi honetan, gauza bitxiagorik ere. Jakina denez, mendebaldeko euskalkiek, besteek ez bezala, modernizatu dute partizipioak mailegatzeko erabiltzen den atzizkia, iturri-hizkuntzarekin batera, baina, irudi luke, azken bokal zaharra mantenduz: -ado $\rightarrow$-adu (adib. enojadu) eta berrikiago -ao $\rightarrow$-au. Itzuliko gara puntu honetara.

Egokitzapen arau honek motibazio fonetikorik ez duenez, pentsatu behar dugu momentu batean hiztun elebidunek korrespondentzia bat ikusi zutela bi hizkuntzen artean eta korrespondentzia emankor bihurtu dela euskaraz. Latinetik mailegatutako hitzek, jatorriko hizkuntzaren /-u/ bukaera mantendu zuten, besterik gabe: CATTU > katu, CIRRU > kirru, SACCU > zaku, GYPSU > kisu, ANGELU > aingeru eta horrela beste asko. Beranduago, alboko erromantzeetan, /-u/ > /-o/ bilakaera gertatu zenean, hiztun elebidunentzat korrespondentzia bat sortu zen bi hizkuntzen artean, gato $=k a t u, s a c o=z a k u$ eta beste hitz pare frankotan oinarriturik, mailegu berriak egokitzeko erabili eta erabiltzen dena. Erromatarren denboretan sortu bazen arau hau,

26. Kasu honetan azentuzko desberdintasun hau, beste modu batean gauzatua, Goizuetan ere aurkitzen dugu: frutéro vs frutèro. 
oso iraupen luzeko egokitzapen araua izango litzateke hau.

Dena den, badago arrazoia pentsatzeko $u$-bukaeradun mailegu asko eta asko askoz modernoagoak direla eta bukaera honekin hartu zituela euskarak alboko erdara batetik. Egokitze arauaren historia ulertzeko egin behar dugun galdera hauxe da: noiz gertatu zen /-u/ $>$ /-o/ aldakuntza maileguen sorburu-hizkuntz(et)an? Ibero-erromanikoaren kasuan, ziur asko ez erromatarren garaian, baizik eta askoz beranduago.

Oraindik ere, Asturiasko hizkera batzuek mantendu dute jatorrizko bereizkuntza bukaeretan: lat. $\overline{M U}_{\mathrm{RU}}(\mathrm{M})>$ ast. $m u r u$, lat. $\mathrm{M} \overline{\mathrm{U}} \mathrm{ROS}>$ ast. $\operatorname{muros}$, lat. LUPU(M) $>$ ast. llobu, lat. LUPOS $>$ ast. llobos, etab. (gogoan har, mendebaldeko hizkuntza erromanikoetan, izenen singularra eta plurala latinaren akusatibotik datozela ia beti).

Daukagun ebidentziaren arabera, Gaztelako iparraldeko eskualde batzuetan ere, Burgostik iparraldera, berandu arte mantendu zen bukaerako /-u/ bokala (Menéndez Pidal 1980 [1950]: 172).

Nafarroako erromantzeari dagokionez, bereziki interesgarria da Quintanak eta Révah-k (2004) argitaratu duten XIV. mendeko dokumentu bat. Dokumentu hau siddur bat da; hau da, testuak juduen bazkorako ohar erritualak biltzen ditu. Honelako testu guztietan bezala, ohar hauek lekuan erabiltzen zen hizkuntzan daude idatzita, dokumentua hebraieraren hizkiekin idatzita badago ere. Quintanak eta Révahk erakusten dute testuaren hizkuntza nafar-aragoiera dela eta esaten dute badaudela arrazoiak pentsatzeko, zehazkiago Nafarroako Tutera-aldeko hizkera dela dokumentukoa. Hebraierazko testuetan bokalak ez dira idazten normalean, baina bada bokalak transkribitzeko tradizio bat, puntuak jarriz, hizkien azpian eta gainean. Gure testu hau bokalizatuta dago. Are gehiago, testu honetan azentu lexikala ere adierazten da bokal luzeetarako diakritikoak erabiliz. Honelako adibideak aurkitzen dira, artikulu-egileen transkribapenean:

\section{Bebrán cáda únu so básu y labarseán las manos \\ Tomarán del ápiu \\ Y emplirán los básos \\ Y çenarán y désque abrán çenadu comnán}

Badirudi, beraz, euskararen eremutik oso gertu zeuden hizkera erromantze batzuetan - $u$ etimologikoa mantendu zela askotan pentsatzen den baino askoz beranduago arte, dokumentu gehienetan aurkitzen dugun nafar-erromantzean eta gaztelania ofizialean gauzak bestelakoak baziren ere. Honek gauza asko esplikatuko lituzke. Euskarazko basu 'edalontzi' hitzaren azken bokala, adibidez, ez litzateke egokitzapen arau baten ondorioa, jatorri-hizkuntza Tuteraaldeko erromantzea edo bukaera horri eutsi zion beste hizkera ibero-erromaniko bat baldin bazen. Testu honetan çenadu bezalako forma bat aurkitzeak antzeko ondorio batera eramaten gaitu, mendebaldeko partizipioen - $a d u$ bukaera dela-ta. Berandu arte, bukaerako - $u$ bokala iturri-hizkuntzan bazegoen, euskaldunek ez zuten bukaera aldatu mailegatzerakoan. Hau horrela bada, honek esan nahi du egokitze araua beranduago sortu edo hedatu zela, inguruko erdaretan /-u/ > /-o/ soinu aldaketa orokortu zenean; beharbada XIV. mendean, Quintana eta 
Révahen bokalen transkribapena egiazkoa bada.

\section{Dialektologia dinamikoaren eginkizuna}

Goian, 4. atalean, esan dugunez, gaur euskaraz orokorrak diren berrikuntza batzuk ziur asko EBZa baino modernoagoak dira. Arrazonamendu bera aplikatuz, espero dezakegu isoglosak historian zehar aldatu direla. Euskararen dialektoak kontaktuan daudenez, berrikuntzek euskalki nagusien mugak gainditu dute sarritan, Euskal Herri osora zabaldu ez badira ere. 5. atalean aztertu ditugun zenbait gertakari fonologikoren esparru geografikoa ere aldatu da azken mendeotan. Kontsidera ditzagun beste adibide batzuk.

Urgellek (2006) erakusten duen moduan, lehen testuetatik, aditz izeneko -tze atzizkiaren erabilera zabalduz joan da eta -te atzizkierena, aldiz, murriztuz, euskalkien mugez gainetik. Bi atzizkiak EBZari badagozkio ere, bakoitzaren testuinguru morfolologikoa aldatuz joan da geografian ordutik hona.

Alderdi interesgarri bat da bi kasu jakinetan -tze ez dela erabiltzen inongo dialektotan: (1) txistukari baten ondoren (hasten, hazten, ixten eta ez **hastzen) eta (2) -n-ez bukatzen diren aditzekin (joa(i)ten, ema(i)ten emo(i)ten, eta ez **joatzen). Lehen kasuan, murriztapen fonologiko bat dugu; alegia, ${ }^{* * / S t s / ~ s e k u e n t z i a ~ s a i h e s t e n ~ d a . ~}{ }^{27}$

Bide batez esanda, paralelo zehatz bat erromantzeetan aurkitzen dugu. Modu orokor batean, lat -TIŌNE > errom [-tsjon] (cf. esp nación, situación, acción, mención, etab), salbu eta -stiōNE baldin badugu (cf. sugestión, gestión, digestión, bastión eta ez *sugesción). Beraz, hemen ere $* * / s t s /$ kontrako disimilazio murriztapena dugu.

Beharbada eman bezalako aditzekin ere murriztapenaren arrazoia fonologikoa zen: afrikatua ez zen onartzen diptongo sudurkaritu baten ondoren **/-ãjtse/. Beraz, -te eta -tze atzizkien eremu geografikoa aldatu da azken mendeotan, baina beti ere bi murriztapen hauek errespetatuz.

Bigarren adibide bat emateko, L.L. Bonaparterentzat hain garrantzitsuak ziren "bokal eufonikoak" oso aldakorrak dira diakronikoki. Markinan, adibidez, buruba, mendidxa esaten zen Mogeldarren garaian. Gaurregun, aldiz, buru(e), mendixe, aurkitzen dugu Markinako hizkeran. Beraz, garai batetik bestera eufoniek definitzen dituzten hizkuntza eremuak oso desberdinak izan daitezke.

"Eufonia" jakin bat etsenplubide hartuz, a > e / i,u (C)__ arauak (laguna > lagune) gaur egun oso zabalera handia du Hegoaldean: ia Bizkaia osoa, Gipuzkoako hegoaldeko zati

27. Badira beste bi aterabide **/Sts/ kontrako murriztapen fonotaktikoa ez bortxatzeko honelako aditz izenetan, cf. hasitzen, hatsen (Urgell 2006: 944). 
bat eta Nafarroako mendebaldeko beste zati bat, Baztaneraino (Zuazo 2014: 265-267). Bere eremu geografikoa ez dator bat euskalkiak mugatzeko erabiltzen diren isoglosekin. Gainera bi zatitan banatuta agertzen zaigu arauaren eremua (ikus Zuazok 2014 ematen duen mapa). Ez dakigu —edo nik ez dakit, behintzat — non edo noiz sortu zen berrikuntza hau eta ekialdetik mendebalderantz hedatu den edo alderantziz; baina edozein kasutan ez da zahar-zaharra eta posible izango litzateke honetaz informazioa jasotzea testuetatik. Mendebaldea dela-ta, Refranes y Sentencias (1596) eta Lazarraga (1588) bezalako XVI. mendeko testuetan ez da kausitzen, baina Ulibarrik (2009) 1596-1640 urte tartean kokatzen duen Viva Jesus testuan lekukotzen da (Ulibarri 2010) eta Ulibarrik (2015) aztertu dituen XVIII. mendeko Arabako iparmendebaldeko sermoietan maiztasun handia du. Ez dakit Gipuzkoako eta Nafarroako testuek zer erakusten diguten arau honi buruz.

Azken adibidea: posible da bizkaiera edo mendebaldeko euskalkiaren sorkuntza singularreko /a+a/ > /ea/ disimilazioarekin identifikatzea. Zuazoren (2010) hipotesiaren arabera, Gasteiztik hedatu zen berrikuntza hau. Lehen testuetatik agertzen zaigu arau hau mendebaldean eta goiko paragrafoan aipatutako asimilazioa baino askoz zaharragoa izan daiteke, dudarik gabe (Manterolak 2015a Ertaroko Elhorzahea aipatzen du). Bere eremu geografikoa dela-ta, hala ere, aldakuntza berriagoek erakusten digutena ikusita, ez dugu pentsatu behar gaur egun arauak dituen muga geografikoak zaharrak direnik. Guztiz alderantziz, XVII. mendean arau honek markatzen zuen isoglosa eta gaurregun aurkitzen duguna oso desberdinak izan daitezke. Hona beraz euskal dialektologia dinamikoaren eginkizuna: testuen miaketaren bidez isoglosa nagusiak identifikatzea, eta posible den neurrian esplikatzea, garai desberdinetan (ikus Camino 2011 ildo honetatik doan ikerketa eredugarri baterako). 


\section{Aipamen bibliografikoak}

Aldai, G. 2012, "Sobre el origen de Martín Portal, autor de la poesía premiada en Pamplona en 1610". FLV 114, 93-117.

Allen, W. S. 1978. Vox Latina: The pronunciation of Classical Latin, $2^{\text {nd }}$ ed. Cambridge: Cambridge Univesity Press.

Allières, J. 1992. "Gascón y euskera: afinidades e interrelaciones lingüísticas". ASJU 26.3: 801812.

Alonso, A. 1955. De la pronunciación medieval a la moderna en español, Tomo Primero. Madrid: Gredos.

Alonso, A. 1969. De la pronunciación medieval a la moderna en español, Tomo Segundo. Madrid: Gredos.

Ariztimuño, B., Atutxa, U., Krajewska, D., Reguero, U., Santazilia, E., Uribe-Etxebarria, O. \& Zuloaga, E. 2015. Materra: edizioa eta azterketa (1.0) Gasteiz, UPV/EHU. Interneten eskuragarri: https://sites.google.com/site/materraedizioa.

Axular, P. 1643. Gero. Bordele: E. Milanges. [2015, B. Urgell-en edizio kritikoa. Iruñea \& Bilbo: Nafarroako Gobernua \& Euskaltzaindia]

Baddeley, S. 1993. L’orthographe française au temps de la reforme. Genève: Droz.

Beaulieux, C. 1967. Histoire de l'ortographe française. Tome Premier, Formation de l'Ortographe. Des origines au milieu du XVI siècle. Paris: Honoré Champion.

Camino, I. 2008. "Dialektologiaren alderdi kronologikoaz", FLV 40, 209-247.

Camino, I. 2011. "Ekialdeko euskararen iraganaz". Epelde, I., arg., Euskal dialektologia: Lehena eta oraina, 87-153. Bilbo: UPV/EHU [ASJUren gehigarriak, 69].

Camino, I. 2013. "Euskalkien historiaz: Lapurdi eta Nafarroa Garaia”. Gómez, R., Gorrochategui, J., Lakarra, J. \& Mounole, C., arg., Koldo Mitxelena Katedraren III. Biltzarra/ III Congreso de la Cátedra Luis Michelena/ 3rd Conference of the Luis Michelena Chair, 77-140. Gasteiz: UPV/EHU.

Campbell, L. 2011. "La investigación histórica de las lenguas aisladas o ies raro el vasco?". Lakarra, J., Gorrotxategi, J. \& Urgell, B., arg., $2^{\text {nd }}$ Conference of the Luis Michelena Chair/ Koldo Mitxelena Katedraren II. Biltzarra/ II. Congreso de la Cátedra Luis Michelena, 23-40. Gasteiz: UPV/EHU.

Chambon, J.-P. \& Greub, Y. (2002). "Note sur l'âge du (proto)gascon". Revue de Linguistique Romane 66, 473-495.

Córdova, Fray Juan de. 1578. Arte en lengua zapoteca. México: Pedro Bailli. [Berrarg. Arte del idioma zapoteco, 1886, Morelia. Faksimilea, 1987, México: Ediciones Toledo.

Egurtzegi, A. 2014. Towards a phonetically grounded diachronic phonology of Basque. Doktorego tesia, UPV/EHU.

Egurtzegi, A. \& Elordieta, G. 2013. "Euskal azentueren historiaz". R. Gómez, J. Gorrochategui, 
J.A. Lakarra \& C. Mounole (arg.), Koldo Mitxelena Katedraren III. Biltzarra (Gasteiz 2012/XI/8-11), 163-186. Gasteiz: UPV/EHU.

Estornés Lasa, B. 1997. Diccionario español-uskara roncalés/ Erronkariko uskararen hiztegia. Iruñea: Nafarroako Gobernua.

Gilisasti Fano, I. 2003. Urduliz aldeko berba lapikokoa. Léxico del euskera de Uribe Kosta. Bilbao: Rontegui.

Guiter, H. 1989. "Elementos de cronología fonética del vascuence". ASJU 23, 797-800.

Gómez, R. \& Sainz, K. 1995. "On the origin of the finite forms of the Basque verb". Hualde, J.I., Lakarra, J. A. \& Trask, R. L., arg., Towards a history of the Basque language, 235-274. Amsterdam: Benjamins.

Gorrotxategi, J. 1984. Estudio sobre la onomástica indígena de Aquitania. Bilbo: UPV/EHU.

Gorrotxategi, J. 1995. "The Basque language and its neighbors in antiquity" Hualde, J.I., Lakarra, J. A. \& Trask, R. L., arg., Towards a history of the Basque language, 31-64. Amsterdam: Benjamins.

Gorrotxategi, J. 2009. "Vasco antiguo: Algunas cuestiones de geografía e historia lingüísticas". Paleohispanica 9, 539-555.

Herman, J. 1967. Le latin vulgaire. Paris: Presses Universitaires de France.

Hualde, J.I. 1993. "Phonologically unmotivated adaptations in language contact: Spanish Borrowings in Basque." Folia Linguistica 26, 1-25.

Hualde, J.I. 1999. "Patterns of correspondence in the adaptation of Spanish borrowings in Basque". Proceedings of the $25^{\text {th }}$ Meeting of the Berkeley Linguistics Society. General Session and Parasession on loanword phenomena, 348-358.

Hualde, J.I. 2002. "Algunas observaciones acerca de la influencia de la lengua castellana en la fonología del habla vasca tradicional de Bilbao y su comarca". A. Arejita, A. Elejabeitia, C. Isasi \& J. Otaegi, arg., Bilbao. El espacio lingüístico. Simposio 700 Aniversario/Bilboren 700. Urteurrena. Hizkuntza gunea. Sinposioa, 153-162. Bilbo: Deustuko Unibertsitatea.

Hualde, J.I. 2012. "Two Basque accentual systems and the notion of pitch-accent language". Lingua 122, 1335-1351.

Hualde, J.I. 2008. "Acentuación y cronología relativa en la lengua vasca". Oihenart 23, 199217.

Igartua, I. 2015. "Diachronic effects of rhynoglottophilia, symmetries in sound change and the curious case of Basque". Studies in Language 39.3, 635-663.

Irigoien, A. 1984. "Bizkaian o+a elkarketa -oa egiten den eremuko hitz deribatu arruntak azken -o eta -u bokalei dagozkiela, azentua ere gogoan harturik". Euskera 29, 537-594.

Labov, W. 2007. "Transmission and diffusion". Language 83.3, 344-387.

Lakarra, J. A. 1995. "Reconstructing the Pre-Proto-Basque root". Hualde, J.I., Lakarra, J. A. \& Trask, R. L., arg. Towards a history of the Basque language, 189-206. Amsterdam: Benjamins. 
Lakarra, J.A. 2006. "Jaun eta jabe, jaio eta herio, jin eta joan...: etimologiaz eta aditz morfologia zaharraz (Hitz hasierez II)". Fernández, B. \& Laka, I., arg., Andolin gogoan: Essays in honour of Professor Eguzkitza, 575-611. Bilbo: UPV/EHU.

Lakarra, J.A. 2008. "Aitzineuskararen gramatikarantz (malkar eta osinetan zehar)". In X. Artiagoita \& J.A. Lakarra, arg., Gramatika jaietan: Patxi Goenagaren omenez, 451-490. Bilbo: UPV/EHU [ASJUren gehiagarriak, 51]

Lakarra, J. A. 2011. "Gogoetak euskal dialektologia diakronikoaz: Euskara batu zaharra berreraiki beharraz eta haren banaketaren ikerketaz". Epelde, I., arg., Euskal dialektologia: Lehena eta oraina, 155-241. Bilbo: UPV/EHU [ASJUren gehigarriak, 69].

Lloyd, P. 1987. From Latin to Spanish. Philadelphia: American Philosophical Society (Memoirs, 173).

Manterola, J. 2015a. Euskararen morfologia historikorako: artikuluak eta erakusleak. Doktorego tesia, UPV/EHU.

Manterola, J. 2015b. "Ekialdeko erromantzeetako hitzak euskaraz". Lapurdum 19, 405-417.

Martinet, A. 1950. "De la sonorisation des occlusives initiales en basque". Word 6, 224-236

Menéndez Pidal, R. 1980 [1950] Orígenes del español: Estado lingüistico de la Peninsula Ibérica hasta el siglo XI. Madrid: Espasa-Calpe.

Mitxelena, K. 1985. Fonética histórica vasca, 3. arg. Donostia: Gipuzkoako Aldundia. [1. arg. 1961].

Mitxelena, K. 1974. "El elemento latino-románico en la lengua vasca". FLV 6, 183-209.

Mitxelena, K. 1963. Lenguas y protolenguas. Salamanca: Acta Salmanticensia, Univ. de Salamanca. Berrarg. 1990, ASJU-ren gehigarriak, XX.

Mitxelena, K. 1981. "Lengua común y dialectos vascos". ASJU 15, 291-303. Berrarg. , 1987, in Mitxelena, Palabras y Textos 23-33. Gasteiz: UPV-EHU.

Ogura, M. 1990 Dynamic Dialectology: A Study of Language in Time and Space. Tokyo: Kenkyusha.

Ohala, J. J. 1993. "The phonetics of sound change". Jones, Ch., arg., Historical linguistics: Problems and perspectives, 237-78. Londres: Longman

Oñederra, M. L. 2009. "Early bilingualism as a source of morphonological rules for the adaptation of loanwords: Spanish loanwords in Basque". Calabrese, A. \& Wetzels, W. L., arg., Loan Phonology, 193-210. Amsterdan: Benjamins [Current Issues in Linguistic Theory, 307]

Penny, R. 2002. A history of the Spanish language, 2. arg. Cambridge: Cambridge University Press.

Price, G. 1984. The French language: Present and past. London: Grant \& Cutler.

Quintana, A. 2006. Geografía lingüística del judeoespañol: Estudio sincrónico y diacrónico. Bern: Peter Lang.

Quintana, A. 2014. "Judeo-Spanish in contact with Portuguese: A historical overview". Amaral \& A.M. Carvalho, arg., Portuguese-Spanish interfaces: Diachrony, synchrony, and contact, 
65-94. Amsterdam: Benjamins.

Quintana, A. \& I.-S. Révah. 2004. "A Sephardic Siddur with instructions in Aragonese Romance, M.S. Oxford Bodleian Library 1133 (Opp. Add. 8 18).” Hispania Judaica Bulletin 4, 141-151.

Reguero Ugarte, U. 2013. "Euskararen dialektalizazioaren hastapenetarantz: konbergentzia eta dibergentzia prozesuak Erdi Aroan”. R. Gómez, J. Gorrochategui, J.A. Lakarra \& C. Mounole (arg.), Koldo Mitxelena Katedraren III. Biltzarra (Gasteiz 2012/XI/8-11), 431444. Gasteiz: UPV/EHU.

Rollo, W. 1925. The Basque dialect of Marquina. Amsterdam: H. J. Paris [Berrarg., 2006, Bilbo: Labayru ikastegia, J. Kaltzakortaren sarrera eta azterlanarekin].

Trask, L. R. 1997. The history of Basque. London: Routledge.

Sánchez Méndez, J.P. 2013. "La pronunciación en la prolongación americana del español: avances y premisas para su estudio". Echenique Elizondo, M.T. \& Satorre Grau, F. J., arg., Historia de la pronunciación de la lengua castellana. Valentzia: Tirant Humanidades.

Straka, Georges. 1956. "La dislocation linguistique de la Romania et la formation des langues romanes à la lumière de la chronologie relative des changements phonétiques". Revue de Linguistique Romane 20: 249-267. Berrarg., Straka 1979: 193-211.

Straka, Georges. 1979. Les sons et les mots: Choix d'études de phonétique et de linguistique. Estrasburgo: Klincksieck.

Ulibarri, K. 2009, "Viva Jesus dotrinaren azterketa bibliografia materialaren arabera", ASJU 43, 861-872.

Ulibarri, K. 2010. "Viva Jesus dotrina: edizioa eta azterketa", ASJU 44:2, 41-154.

Ulibarri, K. 2015. Dotrinazko sermoitegia: Galduriko hizkerak eta dialektologia historikoa. Doktorego tesia, UPV/EHU.

Urgell, B. 2006. "Para la historia del sustantivo verbal en vasco". In: J.A. Lakarra \& J.I. Hualde, arg., Studies in Basque and historical linguistics in memory of R. L. Trask/R. L. Trasken oroitzapenetan ikerketak euskalaritzaz eta hizkuntzalaritza historikoaz (= ASJU XL), 921948.

Zuazo, K. 2010. El euskera y sus dialectos. Irun: Alberdania.

Zuazo, K. 2014. Euskalkiak. Donostia: Elkar. 